\title{
The Dumbarton Oaks Tlazolteotl: looking beneath the surface
}

Jane MacLaren Walsh

\section{(2) OpenEdition \\ Journals}

Electronic version

URL: https://journals.openedition.org/jsa/8623

DOI: $10.4000 /$ jsa. 8623

ISSN: 1957-7842

\section{Publisher}

Société des américanistes

\section{Printed version}

Date of publication: 15 July 2008

Number of pages: 7-43

ISSN: 0037-9174

\section{Electronic reference}

Jane MacLaren Walsh, "The Dumbarton Oaks Tlazolteotl: looking beneath the surface", Journal de la Société des américanistes [Online], 94-1 | 2008, Online since 10 June 2013, connection on 02 September 2022. URL: http://journals.openedition.org/jsa/8623 ; DOI: https://doi.org/10.4000/jsa. 8623 


\title{
THE DUMBARTON OAKS TLAZOLTEOTL:
} LOOKING BENEATH THE SURFACE

\author{
Jane MACLAREN WALSH *
}

Some of the earliest and most revered pre-Columbian artifacts in the world's major museum and private collections were collected prior to the advent of systematic, scientific archaeological excavation, and have little or no reliable provenience data. They have consistently posed problems for researchers due to anomalies of theme, material, size, technical virtuosity and iconography. This paper offers a historical and scientific approach to objectively determining the authenticity of unprovenienced pre-Columbian artifacts. Using the Dumbarton Oaks Tlazolteotl sculpture as a case study, the article presents the results of archival research to flesh out the object's acquisition history and analysis using scanning electron microscopy to determine whether pre-Columbian lapidary technology was used to fashion the artifact, or whether it was carved or reworked in modern times. [Key words: Lapidary technology, pre-Columbian museum collections, tool marks, Tlazolteotl, SEM.]

La Tlazolteotl de Dumbarton Oaks: un regard sous la surface. Certains des artefacts précolombiens les plus anciens et les plus révérés qui se trouvent dans les collections privées et les musées parmi les plus importants du monde ont été recueillis avant l'avènement des fouilles archéologiques systématiques et scientifiques, et sont accompagnés de peu de données ou de données non fiables quant à leur provenance. Ces objets ont invariablement posé des problèmes aux chercheurs, en raison des anomalies relatives à leur thème, leur matériau, leurs dimensions, leur virtuosité technique et leur iconographie. Cet article propose une approche historique et scientifique pour déterminer objectivement l'authenticité des artefacts précolombiens sans provenance. Prenant la sculpture de Tlazolteotl de Dumbarton Oaks comme cas d'étude, l'article présente les résultats d'une recherche d'archives pour reconstituer l'histoire de l'acquisition de l'objet. En outre, à partir d'une analyse faite sur les marques d'outils à l'aide de la microscopie électronique à balayage, il examine si celles-ci sont compatibles avec la technologie lapidaire précolombienne ou si elles indiquent que l'objet a été ouvragé ou retravaillé aux temps modernes. [Mots-clés: technologie lapidaire, collections précolombiennes des musées, Tlazolteotl, microscope électronique à balayage.]

* Smithsonian Institution, Department of Anthropology, PO Box 37012, NHB 313, MRC 112, Washington, D.C. 20013-7012 [walshj@si.edu].

Journal de la Société des Américanistes, 2008, 94-1, pp. 7-43. CSociété des Américanistes. 
La Tlazolteotl de Dumbarton Oaks: mirando debajo de la superficie. Algunas de las piezas prehispánicas más importantes y admiradas, tanto en las colecciones privadas como en los grandes museos del mundo, fueron adquiridas antes de que la arqueología aplicara técnicas de excavación sistemáticas y científicas, de tal suerte que pocos o ninguno de los datos relacionados con su procedencia, son confiables. Estas piezas han presentado consistentemente un problema a los investigadores debido a las anomalías relacionadas con el tema, materia prima, tamaño, virtuosismo técnico e iconografía. Así pues, para determinar objetivamente la autenticidad de artefactos precolombinos de procedencia desconocida, este artículo propone la combinación de un enfoque histórico con la aplicación de una tecnología precisa. El estudio de la escultura de Tlazolteotl en Dumbarton Oaks sirve para ejemplificar cómo la investigación documental en archivos proporciona datos para reconstituir la historia de la adquisición del objeto, mientras que el análisis de las huellas de manufactura utilizando el microscopio electrónico de barrido permite establecer si la pieza fue elaborada utilizando tecnología prehispánica o si fue fabricada o retocada en tiempos modernos. [Palabras claves: tecnología lapidaria, colecciones precolombinas de museos, marcas de herramienta, Tlazolteotl, microscopio eléctronico de barrido.]

A century ago, Dr. Ernest-Théodore Hamy (1906) published « Note sur une statuette mexicaine en wernerite représentant la déesse Ixcuina » in the Journal de la Société de Américanistes of Paris (Figure 1). In the ensuing hundred years, Hamy's Ixcuina, now usually called Tlazolteotl, has been the subject of numerous scholarly articles, and her photograph has graced countless publications. In the title of his article, Hamy asserted that the statue represents the Aztec goddess Ixcuina (Tlazolteotl), that the sculpture is carved from the mineral wernerite and that it is pre-Columbian Mexican in origin. Those facts have only occasionally been disputed in the scholarly literature since then, but these assertions do not appear to stand up to scrutiny.

This Tlazolteotl is now one of the best-known sculptures in the Robert Woods Bliss pre-Columbian Collection at Dumbarton Oaks in Washington, DC. Many scholars consider it to be a masterpiece of pre-Columbian art, highly sophisticated in design and execution (Kelemen 1943; Covarrubias 1957; Mason 1958; Coe 1993; Quilter 2002). Others question its stylistic and iconographic features, and are disturbed by its lack of provenience (Baudez 1998; Pasztory 2002). They believe it is a misattributed, more modern creation. What has been written in support of the sculpture's authenticity since the early years of the 20th century is almost entirely subjective, interpretive and speculative, endlessly repeated, occasionally elaborated. It is axiomatic, unfortunately, that whatever is repeated often enough is eventually taken as fact.

In 2002, Jeffrey Quilter, then director of Dumbarton Oaks pre-Columbian collections in Washington, DC, invited me to study and analyze the Tlazolteotl sculpture (cat.\#B-71). I examined it with a 10x loup, and took silicone impressions of carving, drilling and polishing marks left by the carver. My intention at 


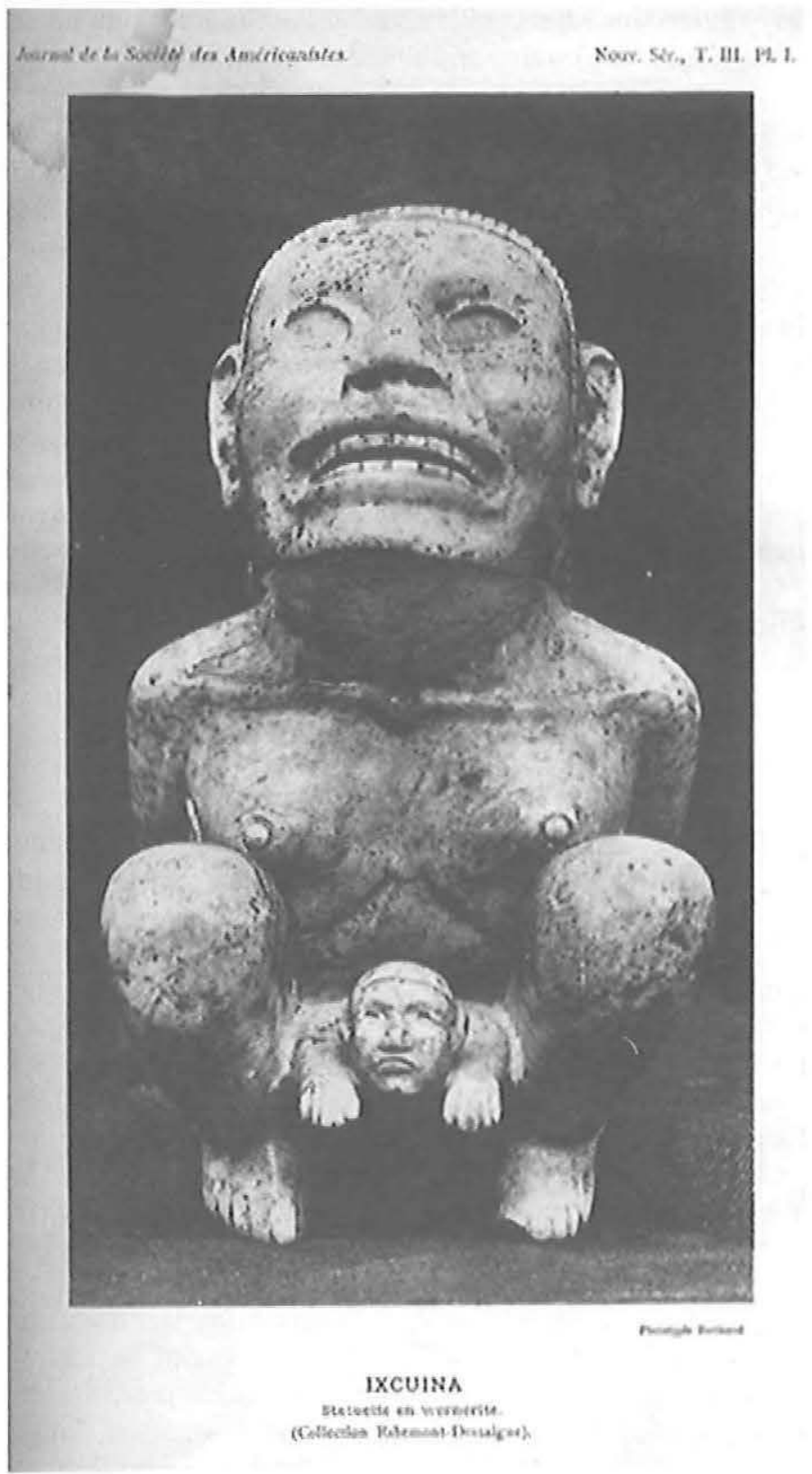

FIG. 1 - Tlazolteotl sculpture: Ixcuina, statuette en wernerite (photo published in 1907, in Journal de la Société des Américanistes). 
the time was to determine what could be said about the actual manufacture of the piece, and additionally to examine and elucidate what has been written about it in the past.

To determine the significance and authenticity of this enigmatic sculpture, I will describe its physical features and anomalies, and clarify its history and cultural origins where possible by presenting the results of my research into published and archival sources. I will review the literature on pre-Columbian lapidary technology and report on the results of my research into whether this work would appear to have been crafted with pre-Columbian tools. To determine that, I used a light microscope and a Scanning Electron Microscope (Amray 1810 with Lab 6 electron source) to examine silicone impressions of tool marks left on the Tlazolteotl and compared them with the marks on documented, archaeologically recovered, hard-stone artifacts. I also compared the marks on the Tlazolteotl with ones made on experimental carvings created in Smithsonian laboratories. In concluding, I will summarize what is known and what is assumed about this artifact, review the problems that arise from unprovenienced artifacts in museum collections, and discuss the potential impact of such artifacts on presentday scholarship.

\section{MATERIAL AND FEATURES}

The Tlazolteotl is sometimes described as being carved from jade or jadeite (Kelemen 1943; Covarrubias 1957), but the sculpture's material was first identified as wernerite by Augustin Alexis Damour (Hamy 1906, p. 4). Damour (1863) was a highly regarded French chemist and mineralogist, who worked extensively with jade, and, in fact, coined the term jadeite. Wernerite was the most common name for minerals which are now referred to as the scapolite group, and have a density or specific gravity of 2.85 . More than a half-century later, the first extensive catalogue of the Bliss pre-Columbian collection makes no mention of Damour's identification, but states the sculpture is carved from « aplite speckled with garnets » (Lothrop et al. 1957, p. 240). Aplite is a type of fine-grained granite, a rock containing quartz and feldspar as the dominant minerals, with a specific gravity of $2.63^{1}$. The discrepancy between the identification of the raw material as a mineral, wernerite, and as a rock, aplite, has not been explained in the literature, at least to my knowledge. Determining the density or specific gravity of a mineral or rock is a relatively simple task, and assuming Damour's original calculation was correct at 2.85 , this would further place the identification of aplite in question ${ }^{2}$. Whether or not the Tlazolteotl is carved from a scapolite, aplite, or perhaps another material, it can be said with certainty that neither wernerite nor aplite is a jadeite, and I know of no other Mesoamerican sculpture carved from either of these materials. 
The sculpture is $20.2 \mathrm{~cm}$ high. She is in a squatting position; more acurately, she is sitting on her hands with her knees drawn up to her breasts. Nearly all features of the sculpture are deeply carved, with the exception of the feet and hands, which are simply incised below her buttocks. Her large head is thrown back, tightening the muscles of the neck and breasts and exagerating the clavicles and shoulder muscles. The breasts, carved with idiosyncratic detail, almost rest on her knees. Her mouth is stretched in a broad grimace, displaying sixteen teeth; the open-space between the upper and lower teeth is deeply cut into the stone. Her nose and rather large ears are realistically rendered; her almond-shaped, inset eye sockets lack elaboration or inlay, or evidence of inlay. The hair is depicted by a series of evenly cut parallel lines running from a ridge across the top of her forehead down to the middle of her back, almost to the waist. Although the statue is usually displayed with a prop beneath the buttocks to tilt it forward, it does in fact stand, or rather sit, on its own.

An infant is shown emerging from the mother, revealing the head, shoulders, arms and torso. Its hair is a simple line, and the ears are large and protruding. The face has a wide nose, a mouth turned down in a determined pout and a square-cut chin. The infant's eyes are different from the mother's, having been cut with a hollow drill, which has left a circular depression and central core or septum. In the case of the figure's right eye, the artist widened the circle into an oval by drilling (at least) twice and removing the septum. The clavicles, like the mother's, is exaggerated and similarly carved. The arms are outstretched, and hands turned down with the fingers carved in such a way as to make the hands look like paws.

There are a number of perfectly round holes drilled into the mother, including holes through the hairline above the center of the forehead, others just in front of the top of each ear, more through the earlobes and below the ears through the jaw, some on either side of the hair at shoulder-level and others at either side of the buttocks and through both feet.

The essential nature of the sculpture is almost completely anomalous with regard to the accepted canon of Mexica art, and does not in fact resemble any other Mesoamerican art form. The choice of stone, the complicated carving in the round, the birthing position, the facial expression of the mother, the somewhat grotesque realism, the lack of iconographic detail all point to a highly idiosyncratic work.

\section{Provenance}

\section{Publication and exhibition history}

The first photograph of Tlazolteotl appeared in Hamy's article (Figure 1). As president of the Paris Americanist Society and chief curator of the Trocadero 
Museum, he was a recognized authority on pre-Columbian artifacts. He considered the statue to be important, describing it as "une femme, d'une verité ethnique tout à fait saisissante » ${ }^{3}$, which had been " acquired by M. Damour, the mineralogist from the Academy of Sciences, well known for his magnificent collection of hard stone worked by fire » (Hamy 1906, p. 3). Fifty years later, in Robert Woods Bliss collection: pre-columbian art, Samuel K. Lothrop (in Lothrop et al. 1957, p. 241) commented that Damour had not acquired it for « a geological collection as has been stated, but for what has been described as a "magnifique collection de pierres dures travaillées" "). Why Lothrop felt the need to clarify the exact nature of Damour's collection is not known, nor is it clear that Hamy and Damour believed the statue had been carved or polished employing fire or heat, but Hamy did write " pierres dures travaillées par le feu ".

The sculpture later became the property of Hamy's « colleague and friend Dr. Ribemont-Dessaignes, of the Academy of Medicine » (Hamy 1906, p. 3). The Lothrop catalogue repeats this information as well, adding that the doctor had in fact purchased the statue, and it was not « as a fee from an impoverished patient, as legend would have it » (in Lothrop et al. 1957, p. 241). The source of this legend is unknown; Hamy makes no mention of it. Another famous unprovenienced sculpture, the obsidian monkey bowl, carries a nearly identical « legend ». It was sold to the Museo Nacional by a physician, Dr. Rafael Lucio, who purportedly received it in payment from an impoverished patient (Boban 1884, p. 70; Walsh 2004, p. 66).

Hamy $(1899$, p. 11) wrote that he had previously seen the sculpture, when it was in the shop of a Paris antiquities dealer, and in a footnote noted that he had, in fact, alluded to its existence in a prior publication ${ }^{4}$. Indeed, in the commentary published with the facsimile edition of the Codex Borbonicus in 1899, while describing the attributes of the Tlazolteotl depicted in that Codex, Hamy wrote that Damour, of the Institute, owned « a curious Mexican sculpture which represents the same subject " (ibid.). The Lothrop catalogue repeats the information about the piece's prior existence in a Paris antique store, from which he assumes it was purchased by Damour (in Lothrop et al. 1957, p. 241).

The antiquities dealer Hamy referred to was Eugène Boban Duverge, who had shops in Paris and Mexico City (Walsh 1996, 2004, 2006; Riviale 2001). Boban had a long-term personal and professional relationship with Damour, documented in their correspondence beginning in 1868 and lasting until 1900 (Bibliothèque nationale, nafr21477). Boban $(1881 ; 1886)$ credited Damour with the mineralogical identification of his pre-Columbian stone carvings in at least two published sales catalogues. Hamy and Boban were correspondents and members of the same academic societies (Bibliothèque nationale, nafr21477).

Hand-written notes forming part of a collection of Eugène Boban's manuscripts clarify Hamy's reference to the antiques shop in Paris. The collection, consisting mostly of drawings, photographs and notes on scraps of paper 
detailing objects collected, traded and sold, was purchased by Archer Milton Huntington from the German book dealer Karl W. Hiersemann in 1909, a year after Boban's death in Paris. It is now housed in the Hispanic Society of America in New York City, which Huntington founded (HSA, B2240-B2254). A single sheet of paper; written on both sides in Boban's hand, contains a detailed description of his first encounter with the Tlazolteotl sculpture, which Damour brought to his shop on boulevard San Michel. The note describes the sculpture in considerable detail, and there is no doubt that he is talking about the statue now in the Dumbarton Oaks collection. The page is dated « Monday, May 28, 1883 » and the first sentence reads, "A divinity, most probably Mexican, was shown to me by M. Damour, and which according to Dr. Hamy was purchased by M. Wan, \#d, rue de Seine, at the auction house for the price of 200 francs, [now] asking $1000 \mathrm{~F}$. (HSA, B2245). Boban wrote that the piece was about $20 \mathrm{~cm}$ high, carved from a « not very hard whitish stone ». The long straight hair, which he felt had more in common with Egyptian carvings, caught his attention. In what is perhaps the earliest speculation on the sculpture's origins, he wrote « the piece is pre-Aztec, it isn't Maya, unless I'm wrong... it seems to me to be Toltec and should come from the Mexican gulf coast between Tampico and Veracruz ${ }^{5}$. In conclusion, he expressed the view that the price of 1000 francs was not a fifth of its actual value (HSA, B2245) (Figure 2).

To retrace the sculpture's early known travels, it was purchased from $\mathrm{Mr}$. Wan by Augustin Damour. After Damour's death in 1902, it became part of the collection of Dr. Ribemont-Dessaignes, where it remained for an undetermined time, perhaps until his death in 1940 (Grand dictionnaire encyclopédique Larousse 1984, p. 896).

In 1910 a photograph of the sculpture appeared in a book entitled $L a$ obstetricia en México, written by Dr. Nicolas León. León (1910, p. 21), an obstetrician, pediatrician, naturalist and anthropologist, noted that « the execution of this statue is admirable for the truth in all it portrays; [...] The whole body is engaged in a savage effort $»$. The doctor concludes a fairly graphic description of the sculpture adding his personal opinion: «In my view this must [my emphasis] have been the typical posture, for birth, among the nahua ». He decides this despite the fact that on the same page in his book, as well as the next, are two different codex depictions of birth. One shows a woman seated on a cushion with one leg bent; she is holding a child still attached to the umbilical cord. The other is a depiction of the Tlazolteotl in the Borbonicus codex, who wears an elaborate headdress, is clothed in the flayed skin of a sacrificial victim, and sits with arms and legs spread wide apart (ibid., pp. 21-22).

Michael Coe (1993, p. 286) wrote that the sculpture once belonged to the art dealer Charles Ratton in Paris, although he gives no source for this information. According to the Lothrop catalogue (in Lothrop et al. 1957, p. 239), Joseph Brummer, artist/collector/dealer, purchased it from another Paris antiques dealer, 


\section{nor Y'II

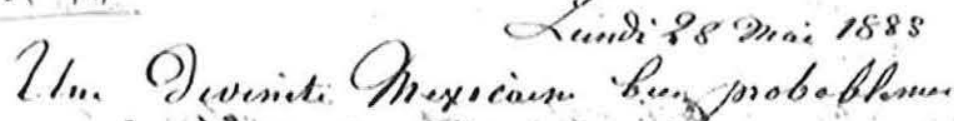

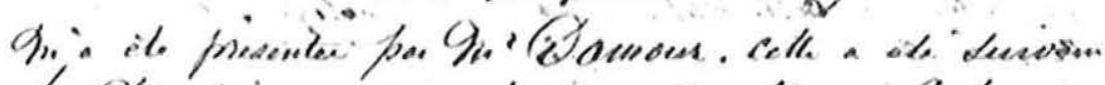

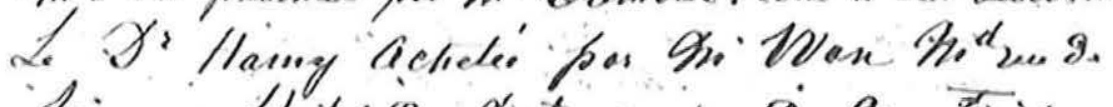

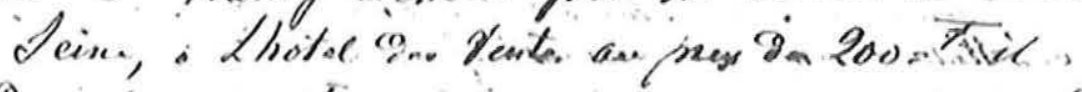

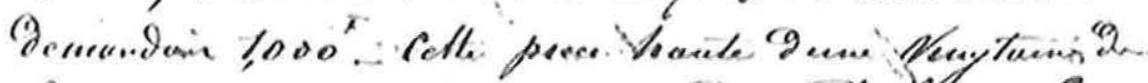

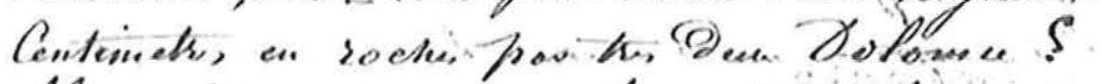

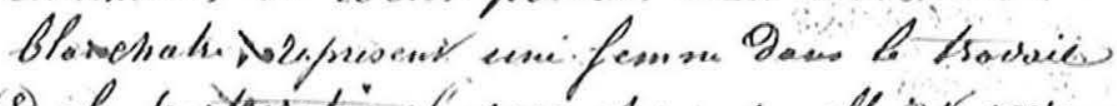

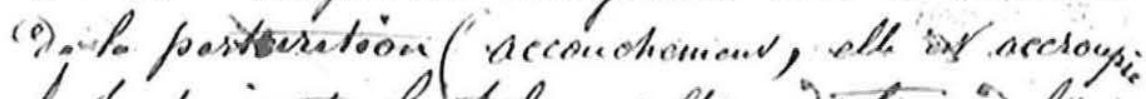

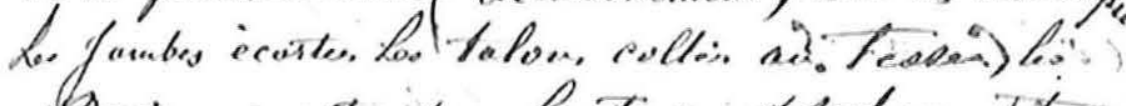

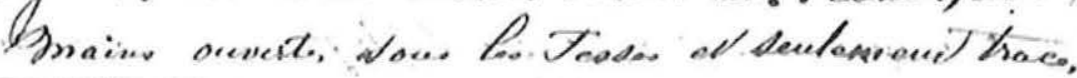

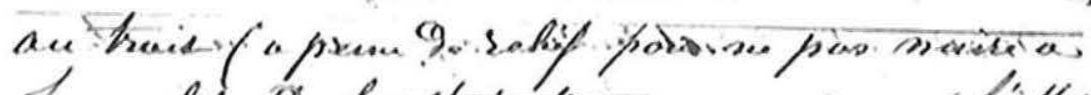

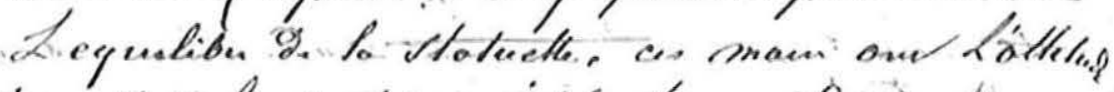

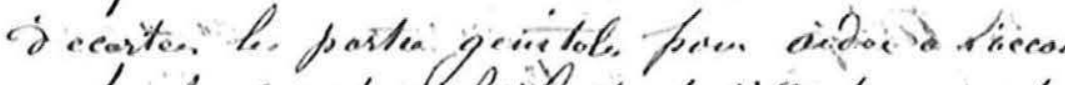

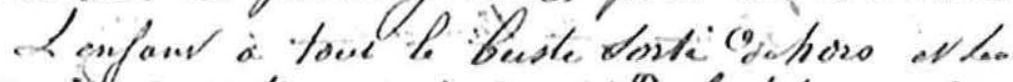

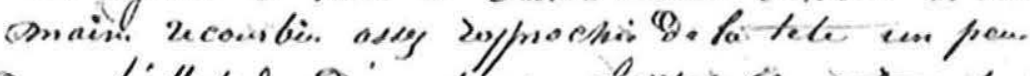

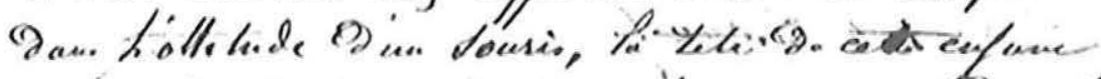

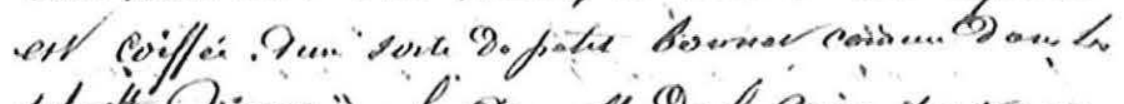

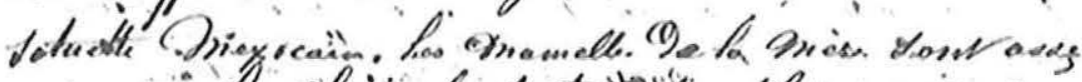

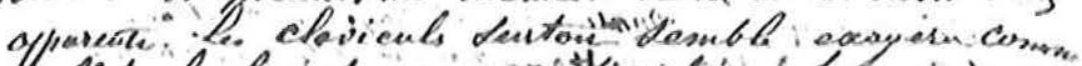

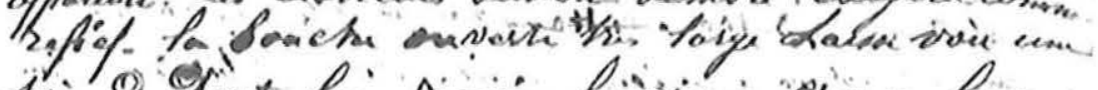

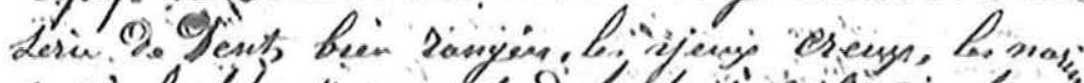

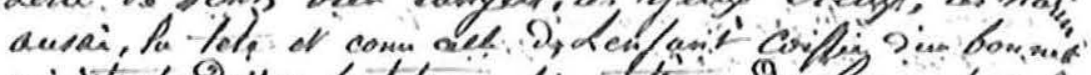

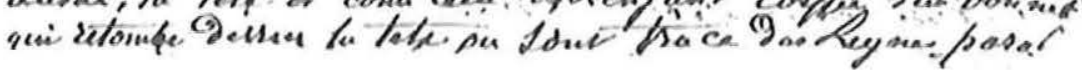

FIG. 2a 


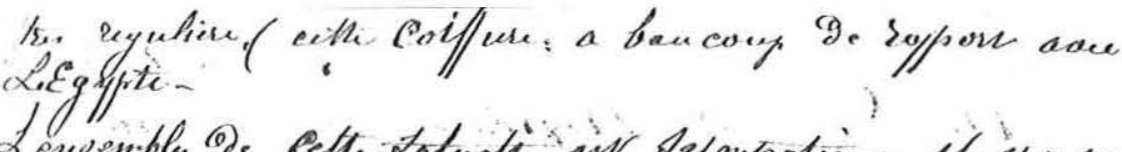

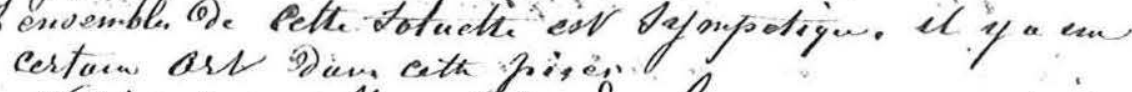
of chose rase ell est ronde boses coym milipa.

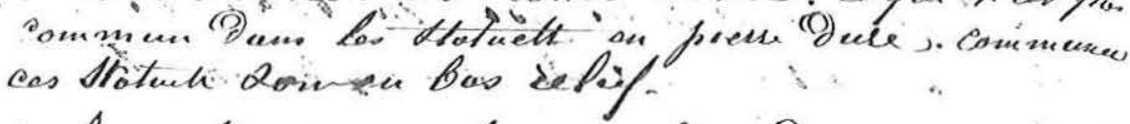

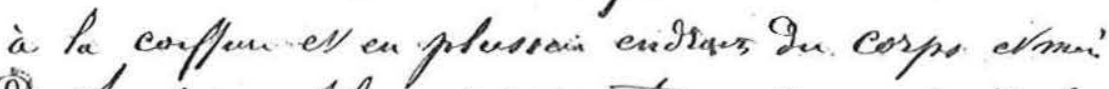

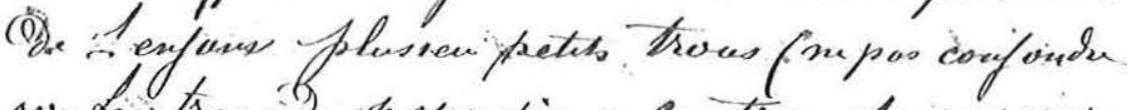

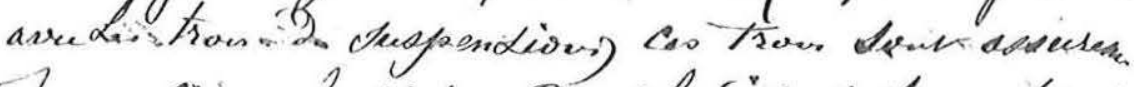

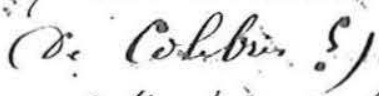

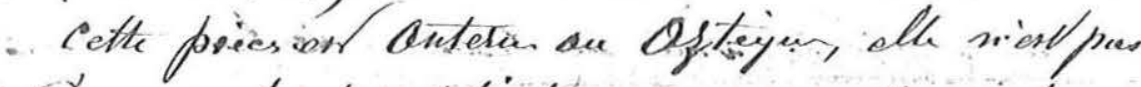

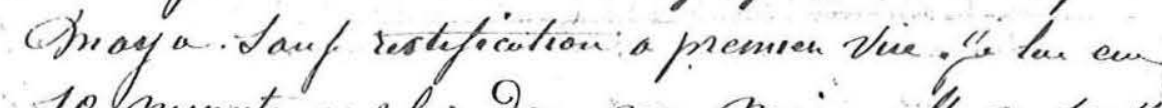

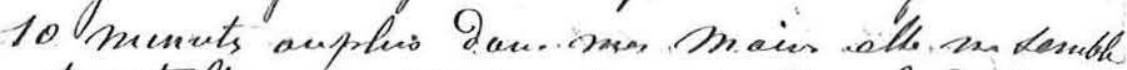

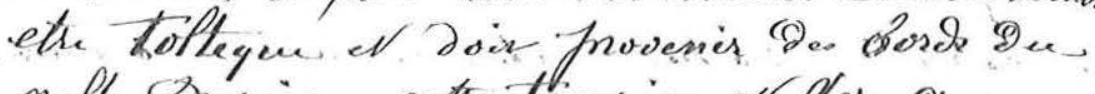
golfe Orrexiem enthe tampico at Vera creng

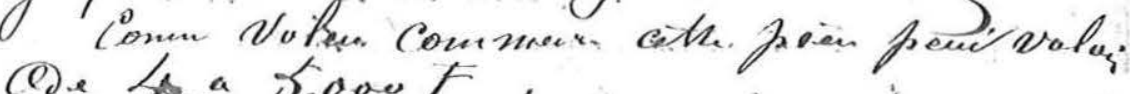

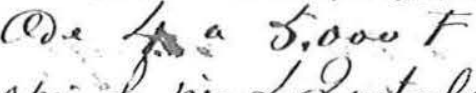

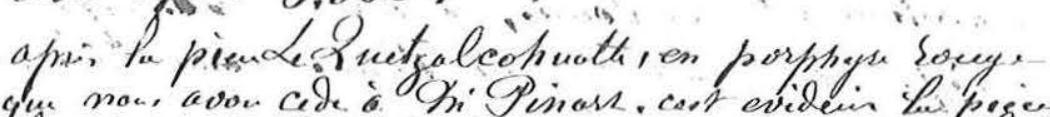

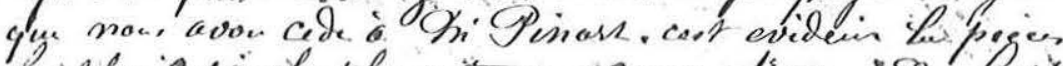

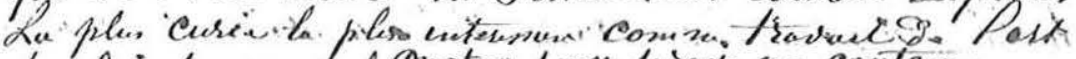

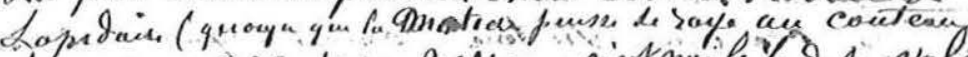

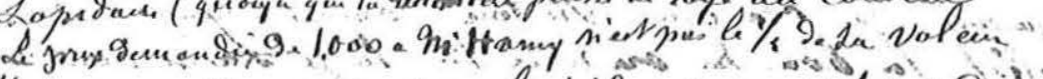

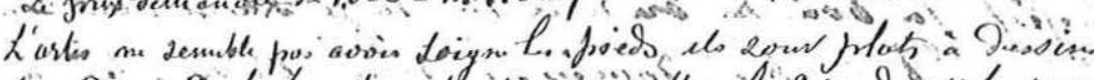

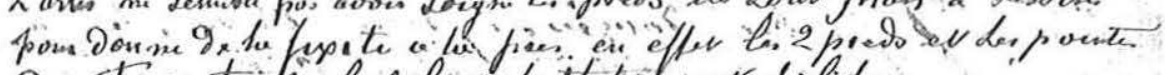

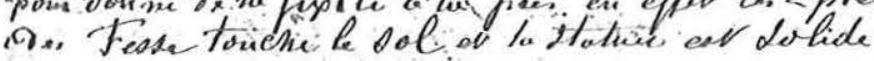

FIG. 2a et b-Eugène Boban's handwritten note describing his first encounter with the Tlazolteotl or Ixcuina figure as seen in figure 1, HSA \#B2245. 
perhaps Ratton, some time in the 1940s. Ratton might have acquired it from the estate of Dr. Ribemont-Dessaignes. There is no way of knowing whether it was Charles Ratton or Joseph Brummer who created the " legend » about the « impoverished patient » who gave the statue to Ribemont-Dessaignes, but it does sound like the sort of story dealers tell.

In 1943, the Tlazolteotl sculpture appeared in Medieval American Art by Pal Kelemen (1943, p. 307), who described it as a « unique statue... cut from a rather pale mottled jade [sic]... unbelievably smooth over the entire surface ». Kelemen (ibid., pp. 307-308) noted, « when photographed, the statue was tilted forward to stand the figure in a natural [my emphasis] position which was probably achieved in pre-Columbian times by additional props, since then disappeared ». This leveraging of the piece seems to be the case whenever it is exhibited, presumably to achieve this more " natural position », despite the fact that the artist carved the stone to sit squarely and rather securely on its feet and buttocks (HSA, B2245).

Robert Woods Bliss purchased the Tlazolteotl from the estate of Joseph Brummer from his executor and brother, Ernest Brummer, in 1947, and it has been on exhibition as part of the Bliss collection almost continuously until the last few years (due to construction at Dumbarton Oaks).

\section{Cultural context: assumed and assigned}

The sculpture has been described as the goddess Toci, Ixcuina and Tlazolteotl. Yet despite being knowledgable about the Aztec pantheon, Boban (HSA, B2245) described her only as " most probably a Mexican deity ». Hamy (1906) first identified the sculpture as Ixcuina, and Lothrop (in Lothrop et al. 1957, pp. 15-16) later reiterated this, describing her as « the goddess Tlazolteotl, also called Ixcuna or Ixcuina, [who] had multiple functions in aboriginal Mexico. In addition to the Aztec she was worshipped by the Mixtec, Huastec and the historic Olmec. In one aspect she was regarded as the goddess of carnal sin and licentiousness, but as the Eater of Refuse she consumed the sins of mankind ».

While Lothrop accurately describes the Aztec goddess's attributes, the statue itself presents no iconography identifying her as Ixcuina or Tlazolteotl. Among numerous representations of Tlazolteotl in the Fejervary-Mayer codex, she is seated, squatting, kneeling on one knee, kneeling on both knees, and standing. She is occasionally naked, but not in the act of giving birth, and even when unclothed, she always wears her headdress, ear ornaments, nose ornaments, and bracelets. The Dumbarton Oaks sculpture might have been inspired by the Tlazolteotl painted in the Borbonicus Codex, which actually shows the goddess in the act of giving birth to the corn god, Centeotl, but in that depiction, her arms and legs are spread wide apart and " she is completely covered by clothing and attributes, and her face does not betray the least expression " (Baudez 1998). Jeffrey Quilter (2002), among others, proposes a relationship between Tlazolteotl 
as the mother goddess of the Huastecs, and the fact that the Huastecs cultivated cotton and traded finely woven textiles with the Aztecs. He notes that Codex depictions of Tlazolteotl show her with unspun cotton, spindles and tassels in her headdress, and suggests that the numerous "small holes in the ear lobes and about the head of this sculpture » may be for inserting spindles and tassels (ibid., p. 479). This might explain the function of the holes drilled through the ears and hair, but there are also holes drilled through her jaw, through her buttocks and through her feet.

John Pohl postulated that the sculpture might be Tlaxcalan, and part of the Tizatlan altar offerings, saying that it could be « related to either Chalchiuhtlicue or Tlazolteotl, who presided over births ». Taking note of the fact that there are no incised or carved calendrical markings on the sculpture, Pohl (1998, p. 195) proposed that « it lacks feast dates perhaps because the goddesses were patrons of all 260 potential birth days $»$.

\section{Pre-Columbian lapidary technology}

The Dumbarton Oaks Tlazolteotl is fashioned from rare material and displays what Pasztory (2002, p. 161) describes as « exquisite technical virtuosity despite the use of stone tools ". This technical virtuosity seems problematic, particularly when one understands the limitations of an artisan who had only stone and abrasives with which to carve hard materials such as granite, aplite, wernerite, or jadeite.

Mesoamerican lapidary technology has long been of interest to archaeologists. Two of the earliest students of pre-Columbian stone carving were Smithsonian scientists: J. D. Maguire, who wrote « A study of the primitive methods of drilling " (1894) and "Materials, apparatus, and processes of the Aboriginal lapidary » (1892), and W. H. Holmes, who produced the encyclopedic study «The lithic industries » in 1919. More recent books and articles deal with discrete collections of stone carvings from specific cultures or regions, with technological discussions usually kept to a few paragraphs or pages. The exceptions are Lorena Mirambell's « Técnicas lapidarias prehispánicas » (1968), Mark Chenault's 1986 University of Colorado M.A. thesis, «Technical analysis of Pre-Columbian Costa Rican Jadeite », and Margaret Hempenius Turner's 1988 University of Rochester dissertation, "The lapidary industry of Teotihuacán, Mexico » ${ }^{6}$.

Pre-Columbian craftsmen worked hard stones by abrading their surfaces with stone, wood and, perhaps, metal tools in combination with abrasive sand. The 16th Century Aztec informants of Fray Bernardino de Sahagún (1961, p. 14; book 10, part XI, pp. 80-81) described lapidary masters who « cut rock crystal, and amethysts, and green stones, and emerald green jade, with abrasive sand, and hard metal. And they scraped them with a worked flint tool. And they drilled them; they bored them with a metal tubular drill. Then they slowly smoothed the 
surfaces; they polished them; they gave them a metallic luster. And then they finished them off with a piece of wood and very fine abrasive». The "hard metal » to which Sahagún refers might be hammered copper or bronze, although some believe that the metal tools were a post-conquest phenomenon. Smithsonian geologist, William Foshag (1957, p. 46) thought that the hollow drilling tubes used by pre-Columbian artisans were more likely bone or bamboo with abrasive material applied to the cutting edge.

Special sand was brought from various parts of the Aztec empire, including Quetzaltepec and Tototepec on the Pacific coast of Mexico (Durán 1994, p. 417) to be used as abrasives. The material may have included quartz, pulverized garnet and jadeite used with hard stones, wood, agave fiber cord, and possibly even potsherds (Foshag 1957, p. 54; Stirling 1961, p. 56; Pohorilenko 1996, p. 12). In excavations at Kaminaljuyu, Kidder et al. (1946, p. 120) found "about two teacupfuls [sic] of sharp quartz sand, and angular fragments of evidently freshly broken-up jade from the size of a pinhead to that of a pea ». The coarseness of the jade fragments would preclude their being used as abrasive material, although the material might have been saved for later pulverizing.

Pre-Columbian tool kits were essentially neolithic - they carved even hard stones like quartz and jade with other stones. Large stones were « split along the grain or sawed into units with at least one flat surface, probably by means of cords and abrasive powder » (Kelemen 1943, p. 285). To this day, Guatemalans break off jade slabs by using a wooden wedge forced into a natural crack in the stone. By applying water to engorge the wood, they create enough pressure over time to force the sections apart (Sorensen, personal communication in 2004). Other rough shaping of stones was done by grinding and by percussive blows and later sawing individual plaques with stone saws and abrasive sand (Foshag 1957, pp. 45-46; Drucker 1955, p. 172; Stirling 1961, p. 56).

Pre-Columbian lapidaries employed chipping techniques to create particular features, and drilled through hard stone with solid drills made of stone or wood, and later, hollow drills of reed, bone or copper (Kelemen 1943; Foshag 1957; Easby 1961,p. 70; Mirambell 1968, pp. 11-12). These drills may have been rotated by hand, set into a stick and rolled over the thigh or revolved by means of a bow drill (Maguire 1894; Holmes 1919). Several tons of drilled ilmenite cubes were excavated at the Olmec site of San Lorenzo. They may have been used as cap stones in combination with bow drills at what must have been a large lapidary workshop, but no other tools were found in association with this material (Di Castro Stringher 1997, pp. 153-160). Much polishing was accomplished with fine-grained abrasives. This process would have required patience and considerable skill, and lapidaries may have used the finest grade of abrasives in combination with soft-wood blocks or animal skins for a finished polish.

When working with hard stone like jade and quartz, pre-Columbian artisans used a variety of other stones, wooden wedges and drills, cords and possibly 
copper tools, in combination with sand and crushed rock as abrasive. They employed techniques such as chipping and grinding, along with drilling, splitting and sawing to form basic shapes. Sharp-edged stones, probably flint or agate, were used as files, and obsidian with appropriate abrasives was most likely used to incise lines and create indented features. For piercing, they used solid pointed stones, which left cone-shaped holes, and hollow, cylindrical drills with abrasives for creating decorative elements. They employed a variety of polishing approaches, depending on the type of stone. Despite Sahagun's reference to " hard metal », he is describing copper and possibly bronze. There is no indication in any historic or ethnographic source of which I am aware that pre-Columbian lapidaries used what we would consider hard metal, such as iron or steel, as filing, drilling or cutting tools, or that they employed any type of wheeled or rotary technology in fashioning their stone objects.

\section{Scanning electron microscopy}

I believe that microscopic examination of tool marks provides a means of determining whether a stone artifact is ancient or was created or reworked in recent times. Modern tools leave marks distinct from those left by pre-Columbian tools, and by employing Scanning Electron Microscopy (SEM) these differences can be detected.

The silicone molds from carved elements on the Dumbarton Oaks Tlazolteotl, which I took in 2002, were examined under SEM, and compared with impressions of tool marks from two groups of carvings. The first group was comprised of documented, archaeologically recovered, pre-Columbian stone carvings, including Olmec jade and quartz carvings from La Venta, Tabasco, in the collections of the Smithsonian Institution, and Aztec and Mixtec greenstone and travertine carvings from the Templo Mayor Museum collections in Mexico City. The second group was comprised of experimental tool marks made on Guatemalan jadeite and Mexican quartz crystal in a Smithsonian laboratory using modern, diamond-coated files, wire saws and rotary cutting tools.

All of the tool marks examined fall within four basic stone carving techniques as described by Margaret Sax of the British Museum; these include micro chipping (characterized by a pitted surface), drilling (forming circular and semicircular features), filing (showing linear features) and wheel cutting (with curved or linear features) (in Sax et al. 2004, p. 1414). Wheel cutting, as previously noted, is unknown to pre-Columbian lapidary technology, and wheel-cut features are not present on any securely documented pre-Columbian objects thus far examined. The presence of such tool marks is therefore presumed to be evidence of the use of modern rotary saws or lapidary wheels.

Scanning electron microscopy (SEM) employs an electron beam to scan the surface of a specimen, and requires that a conductive coating of gold or palla- 
dium be applied to each specimen for imaging to take place. In this instance, because of the size of the object as well as the possibility of damaging it, silicone impressions were employed to preclude coating the actual artifacts under study. In the SEM photographs, the palladium-coated impressions of carved and incised designs appear as positive features, so that the carved lines, which look like channels on the object itself, appear as ridges in the photos; the holes left by drilling appear as cylindrical or conical projections. In other words, in the photomicrographs of the silicone molds, the carved features appear in the reverse of how they look on the actual artifact.

Although taking silicone impressions has the drawback of creating images that are initially difficult to read because the details are reversed, « an advantage of this approach is the ability to examine details of the deeper parts of engraved features " (Sax et al. 2000, p. 381). That is, one is able to see tool marks in the deep recesses of carved and incised features, where normal polishing techniques could not reach to obscure or erase them. Individual features were viewed in plan view (as seen from directly above), from a side view in order to assess the longitudinal depth and occasionally in cross-section (seen by viewing the end of the feature), which indicates the shape of the tool used (Sax et al. 2004, p. 1414).

\section{Procedure}

Employing a molding material called Coltene, President Plus, which is a light-body, surface-activated silicone that produces high-definition impressions, I made 13 impressions of features on the Tlazolteotl, including the incised markings from the hair and the complicated carving of the ears and teeth, along with the face and hands of the smaller figure. I also took impressions of the polish on the principal figure's face, ribs and buttocks (Figure 3).

I examined the silicone molds under a light microscope, and then prepared each impression for SEM examination by mounting the individual silicone casting on a 1-inch diameter aluminum platform, and coating it with either gold or palladium. I followed this procedure on a selection of Olmec jade and quartz carvings in Smithsonian collections, and Aztec and Mixtec serpentine and travertine carvings in the collections of the Museo Templo Mayor. The purpose of employing this diverse group of carved stone objects was to establish a sufficiently large sample to be representative of pre-Columbian lapidary technology at various points in prehistory, from the Formative through the Late Post Classic.

I took a final set of silicone impressions of a series of straight incisions, saw marks, circular and semi-circular carvings, as well as hollow, conical and bi-conical perforations created on Guatemalan jadeite and Mexican quartz crystal with modern diamond-coated filing, cutting, drilling, and straight and circular sawing tools. I prepared these impressions for the SEM and examined them for 


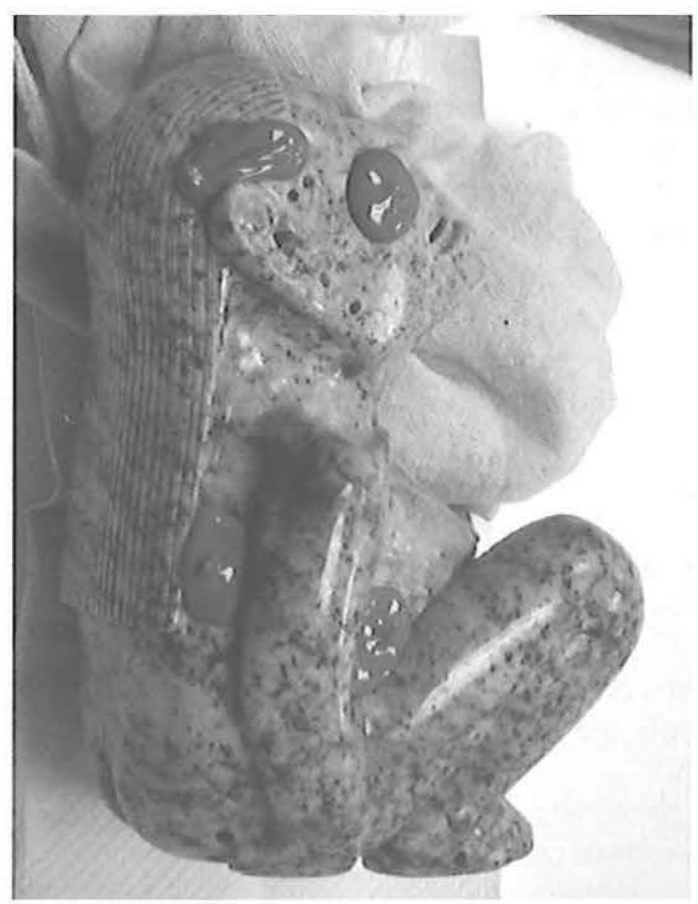

FIG. 3 - Tlazolteotl sculpture at Dumbarton Oaks, Washington, DC, with silicone molding material applied.

comparative purposes alongside the Dumbarton Oaks specimen and the provenienced archaeological materials.

Viewed under SEM, archaeologically recovered pre-Columbian hard stone carvings display carved and engraved features that appear relatively irregular and occasionally erratic, particularly when compared to carving and incising marks left by modern tools. Carved and incised features on documented pre-Columbian carvings show the paths engraved by freely moving, irregularly sized abrasive grains. Generally, unadhered abrasive grains tend to shatter, and cross the paths of other grains. Marks left by hand-held, sharpened stone tools with or without abrasive sand also show a tendency to twist, and falter somewhat, indicating perhaps a natural twisting of the hand as it moves the tool across the stone. In marks left by hollow drilling tools, if the abrasive has become embedded in the tool, the grains appear to line up in more or less concentric arcs. Under higher magnification, however, their appearance is only roughly uniform, and the variant size of abrasive grains is evident. In carved and incised lines created with 
a stone file or cutting tool, with or without abrasive, the back and forth motion of the cutting tool leaves irregular and only roughly parallel lines, and the form and size of the abrasive grains are not uniform.

One example of an engraved feature, appearing to the naked eye as a neatly curving line, is incising made to depict the hairline on a highly polished Aztec mask from the Templo Mayor excavations (Figure 4). Under SEM the incising appears as rough, broken and somewhat erratic (Figure 5).

Circular and semicircular elements created by hollow drills made of bird bone, reed or possibly copper on documented, pre-Columbian objects vary widely in size. The smallest hollow-drilled elements in the documented study group measure from between 6.5 and $7.3 \mathrm{~mm}$ to about $12 \mathrm{~mm}$ in diameter; the largest ones are between 17 and $19 \mathrm{~mm}$, or nearly $2 \mathrm{~cm}$ wide. None of the hollow drills used on Aztec, Mixtec or Mezcala stone carvings from the Templo Mayor excavations has walls less than $1.2 \mathrm{~mm}$ thick, and most are between 2 and $3 \mathrm{~mm}$, which would be consistent with the use of reeds or bones. Hollow drill marks on documented Olmec jades from La Venta excavations, at least those in the Smithsonian Institution's collection, are nonexistent - all Olmec jades examined for this study bore only the marks of solid stone drills, which left cone or domeshaped depressions.

Not surprisingly, there is no evidence of standardized tool sizes on documented pre-Columbian stone carvings; implements made from stone, bone, wood and bamboo would require frequent reshaping and sharpening. Such tools would not leave uniform indentations, perfectly circular impressions and finely cut straight and parallel lines. Additionally, carved lines or incisions made by simple files with abrasive display no curvature and little depth when seen in profile; rather they form simple ruts.

The Mohs' scale is used to determine the hardness of stone, with degrees of hardness ranging from 1 to 10 . Aplite has a hardness of 6 , jadeite is between 6.5 and 7 , chert, flint and quartz are between 7 and 8 and diamond is the hardest, at 10. Diamond abrasives, although not known to have been employed by preColumbian carvers, cut through jadeite and aplite sharply and cleanly, leaving distinctive tracks (Figures 6 and 7).

Since the mid-19th century, available technology has provided lapidaries with cutting tools coated with permanently adhered and uniformly sized abrasives. The abrasives embedded in modern carving tools are industrial diamonds, uniform in size and shape. In experimental incisions, diamond-coated files and saws left paths of neatly parallel lines. In incised lines created by diamond coated steel burring tools, the regular, equidistant, parallel lines are also clearly visible. It is possible to erase or obscure these lines by polishing, but it is very difficult to be entirely successful in this endeavor (Figure 8). In this figure, some of the abrasive grain paths were polished out using a wooden toothpick and dry quartz sand. 


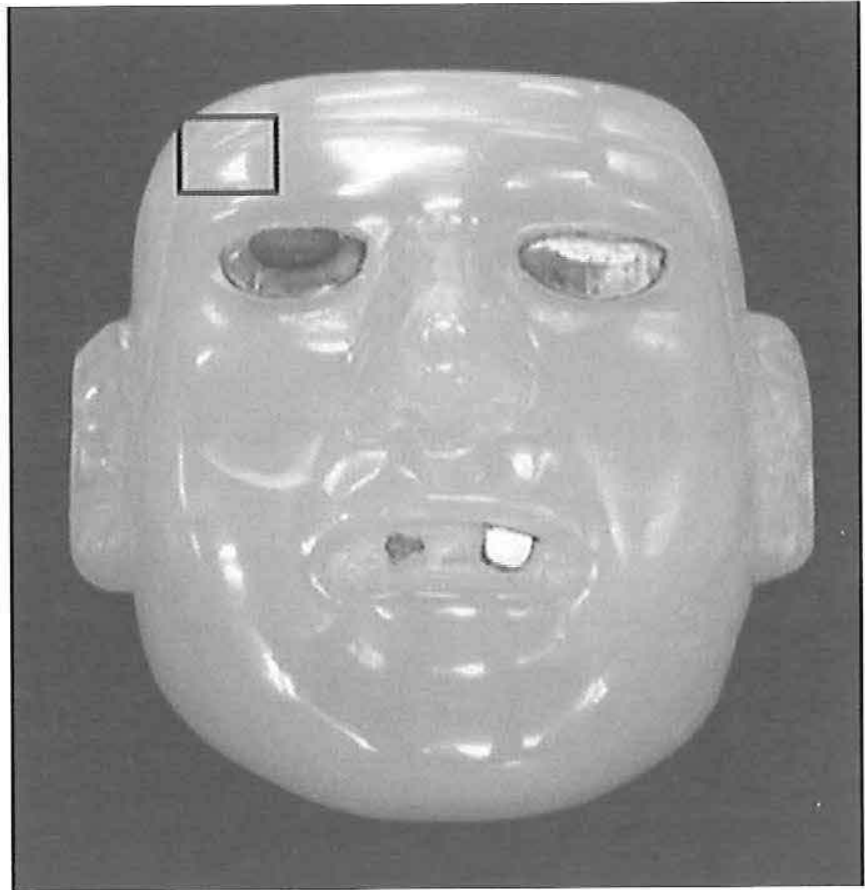

FIG. 4 - Templo Mayor Aztec mask examined in Templo Mayor Museum, Mexico City (10-220298). Superimposed box outlines hairline section recorded in Figure 5.

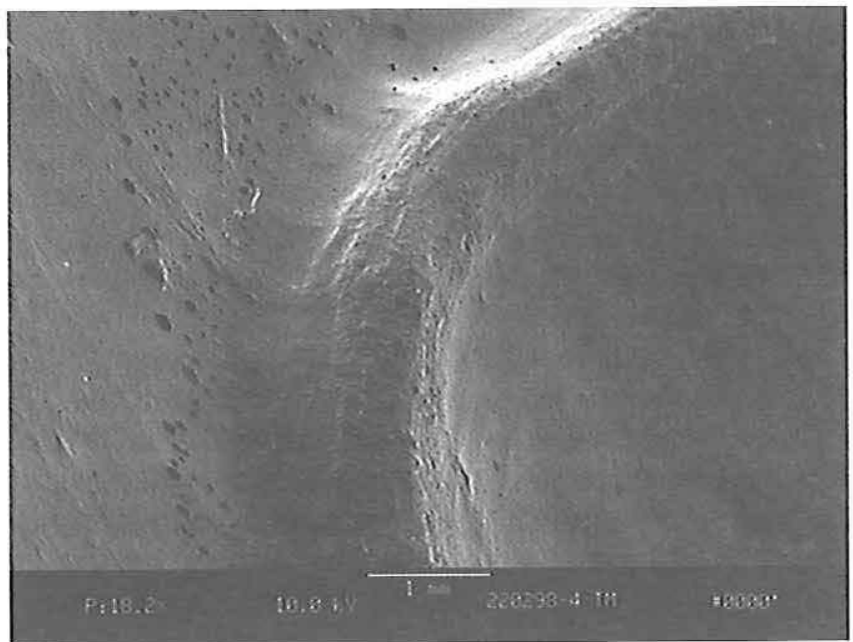

FIG. 5 - Templo Mayor Aztec mask: SEM photomicrograph of incision representing hairline at $18.2 \times$ magnification. Note broken lines and irregular abrasive grain sizes. 


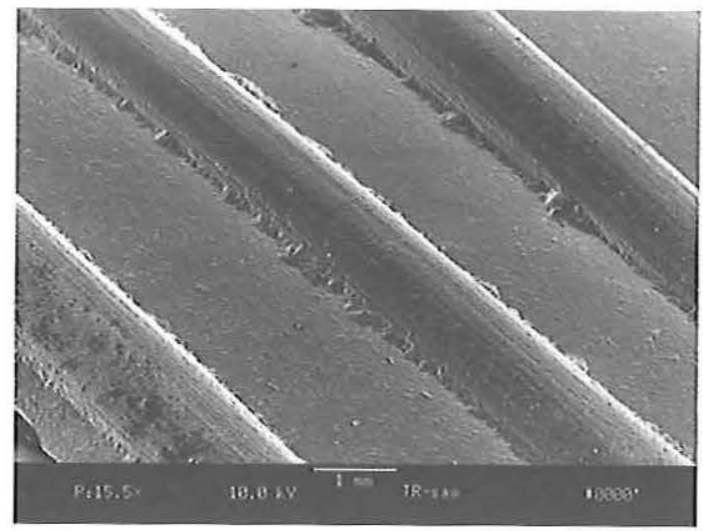

FIG. 6-Experimental tool marks: SEM photomicrograph of incisions made with modern diamond rotary saw at $15.5 \times$ magnification.

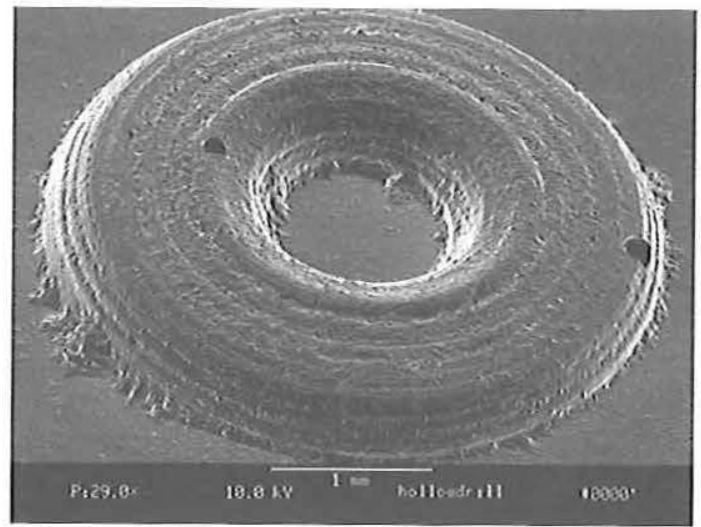

FIG. 7 - Experimental tool marks: SEM photomicrograph of hollow diamond core drill captured at 29-x magnification.

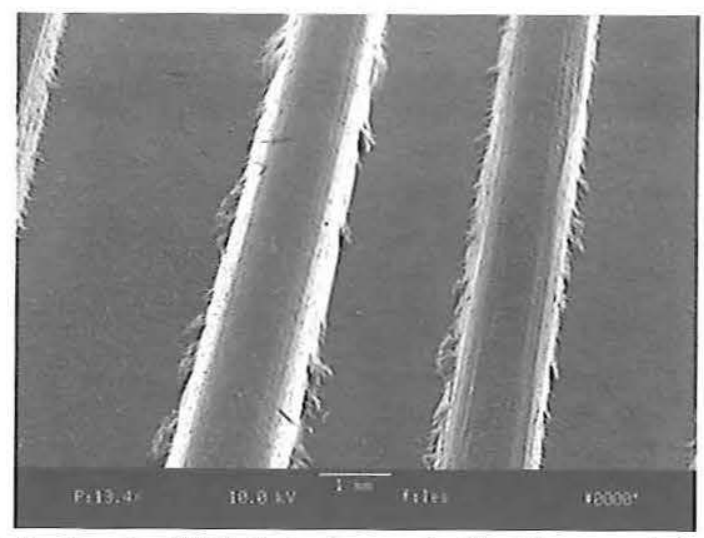

FIG. 8 - Experimental tool marks: SEM photomicrograph of incisions seen in figure 6 after polishing with loose quartz sand abrasive. 


\section{Tool Mark Analysis}

The Tlazolteotl's most arresting images, under SEM, are seen in the complicated carving of her teeth, hair, ears and rib cage. In the process of drilling and carving the teeth, the artisan left distinct indentations on both the upper and lower lips at the ends of each tooth incision. These were not polished out, and are visible in an enlarged digital photo of the mouth (Figure 9).

These lip indentations were created by a solid pointed drill, less than a millimeter in diameter, as seen in an SEM photomicrograph (Figure 10) ${ }^{7}$.

The holes, apparently done first, may be the remains of drilling to remove the section of stone from between the lips. The remnants of these drillings might have served as guides for the carver to make the horizontal cuts for the teeth without going too far into the lips. The shape of this drill hole shows no twisting movement of line, or slippage. In contrast (Figure 11), an SEM photomicrograph of a drill hole from a documented Smithsonian Olmec serpentine carving, clearly shows the wavering and twisting movement of a hand-powered tool.

A very narrow cutting tool was used to create the incisions between the teeth themselves (Figure 10). These incisions, when viewed from a variety of angles, display a depth and curvature of line that could only have been accomplished by means of a rotary cutting device or lapidary wheel, visible in the photomicrograph (Figures 12 and 13). For comparison, see Figure 15, a photomicrograph of incised teeth from a quartz crystal skull, which was created at the request of the author in a shop near Teotihuacan (Figure 14). The carver used a handheld, diamond-coated, rotary cutting device.

In addition to this evidence of rotary saw use, I believe that the tool employed to create the opening between the upper and lower teeth is a diamond coated wire saw, measuring less than $1 \mathrm{~mm}$ in diameter (Figure 13). The opening between the teeth is extremely regular, straight and smooth, and has been cut into the stone almost a centimeter. Pre-Columbian carvers might have used string or cord sawing to achieve this, but the characteristic convex cut left by such sawing is absent. It is difficult to imagine a natural fiber or even a stone tool that would be narrow and strong enough to create this feature. It might be possible to create this with a thin piece of copper, but it too might break under the pressure of sawing through that much material.

The extraordinary carving or incising representing the hair indicates the use of very narrow, needle-like files or, possibly, a large rotary cutting device. The end points for these incisions measure approximately $.25 \mathrm{~mm}$ in width (Figure 16). Considering the hardness of aplite (granite) with garnet inclusions, a preColumbian artisan would have employed a stone file with or without abrasive sand to create the hair lines. Such a tool would necessarily create numerous indications of starts and slips along these lines, since it is difficult to gain purchase 


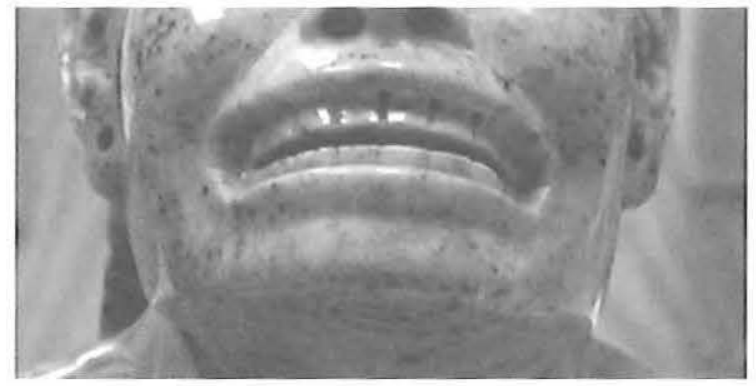

FIG. 9 - Tlazolteotl sculpture: enhanced view of mouth showing teeth with drill entry marks emphasized via Photoshop.

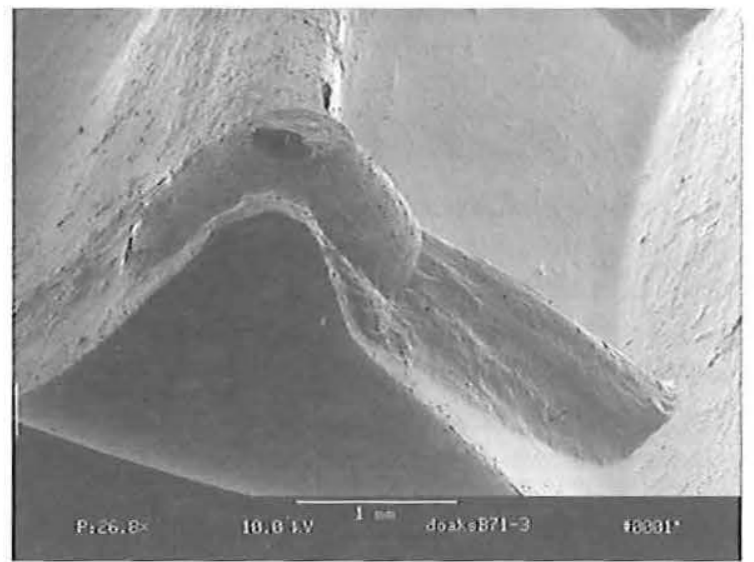

FIG. 10 - Tlazolteotl sculpture: SEM photomicrograph of drill hole at upper lip above incision between teeth. The perfect cone shape of the drill can be compared to the solid drill shown in Figure 11 .

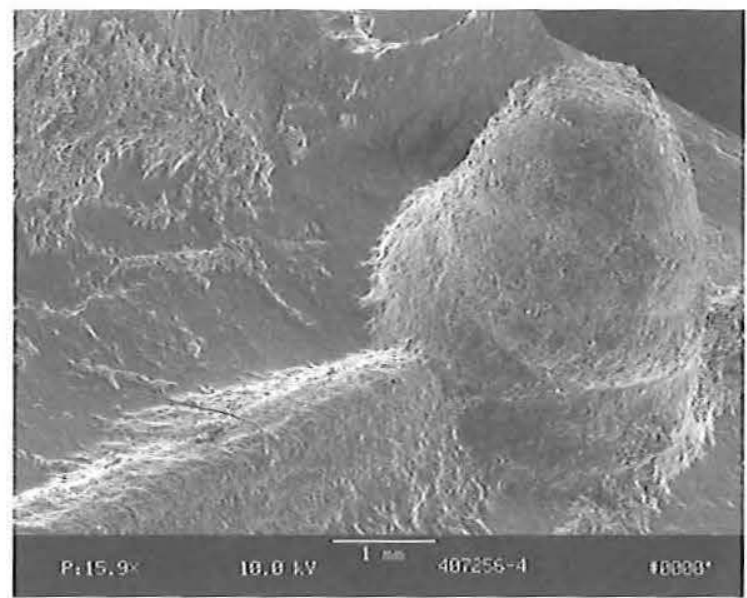

FIG. 11 - Olmec figurine: SEM photomicrograph of drill hole at back of ear. The faltering, twisting 26 movement of this hand-powered drill can be seen in the shape of this conical depression. 


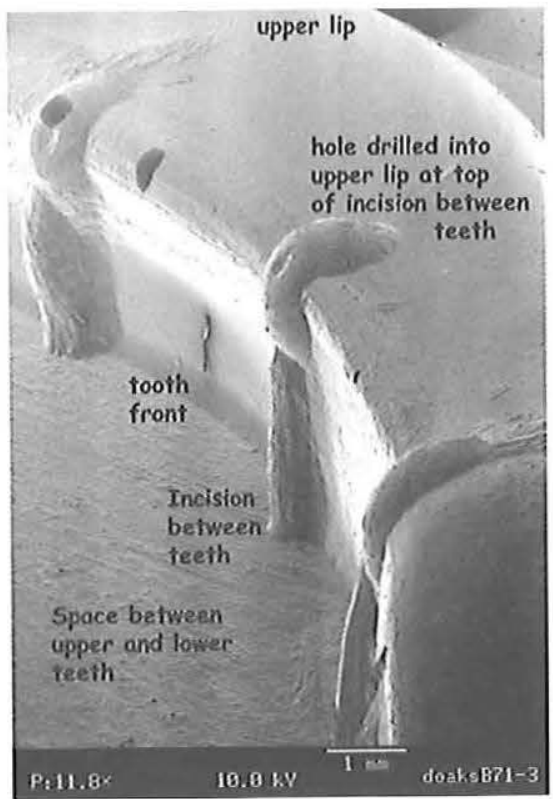

FIG. 12 - Tlazolteotl sculpture: SEM view of upper teeth, showing incisions between teeth, drilled holes and space between upper and lower teeth at $11.1 \times$ magnification.

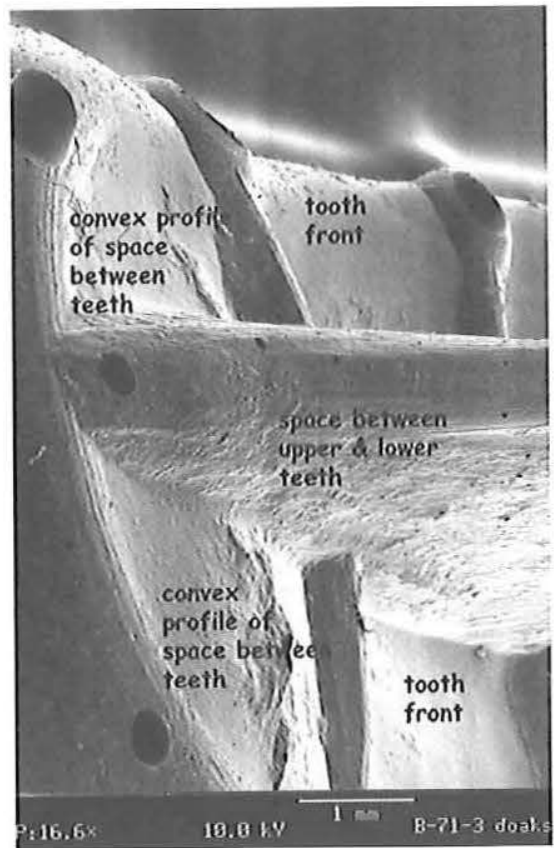

FIG. 13 - Tlazolteotl sculpture: SEM photo micrograph of upper and lower teeth, showing convex profile of line creating the space between the teeth in foreground, captured at $16.6 \times$ magnification. 


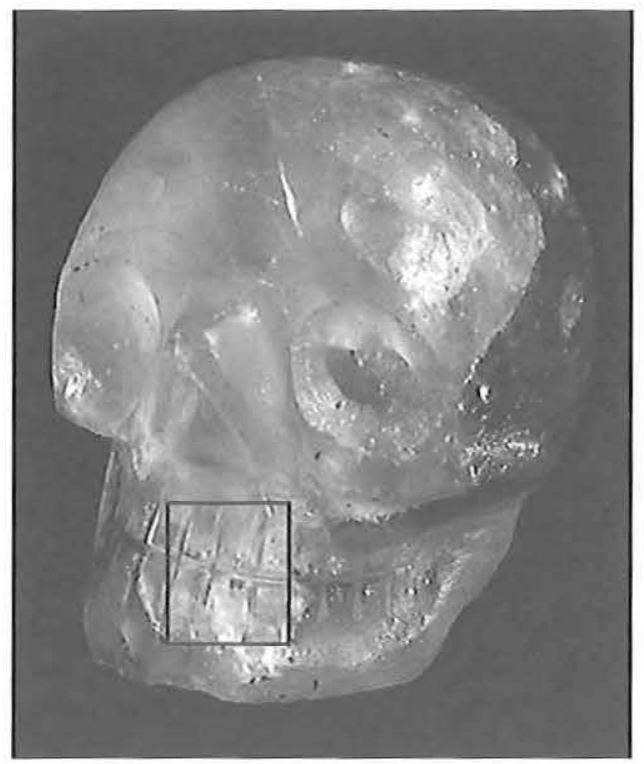

FIG. 14 - Modern rock crystal skull; carved in Mexico for author using modern electric hand-held diamond-coated rotary cutting device. Superimposed box outlines area recorded in figure 15.

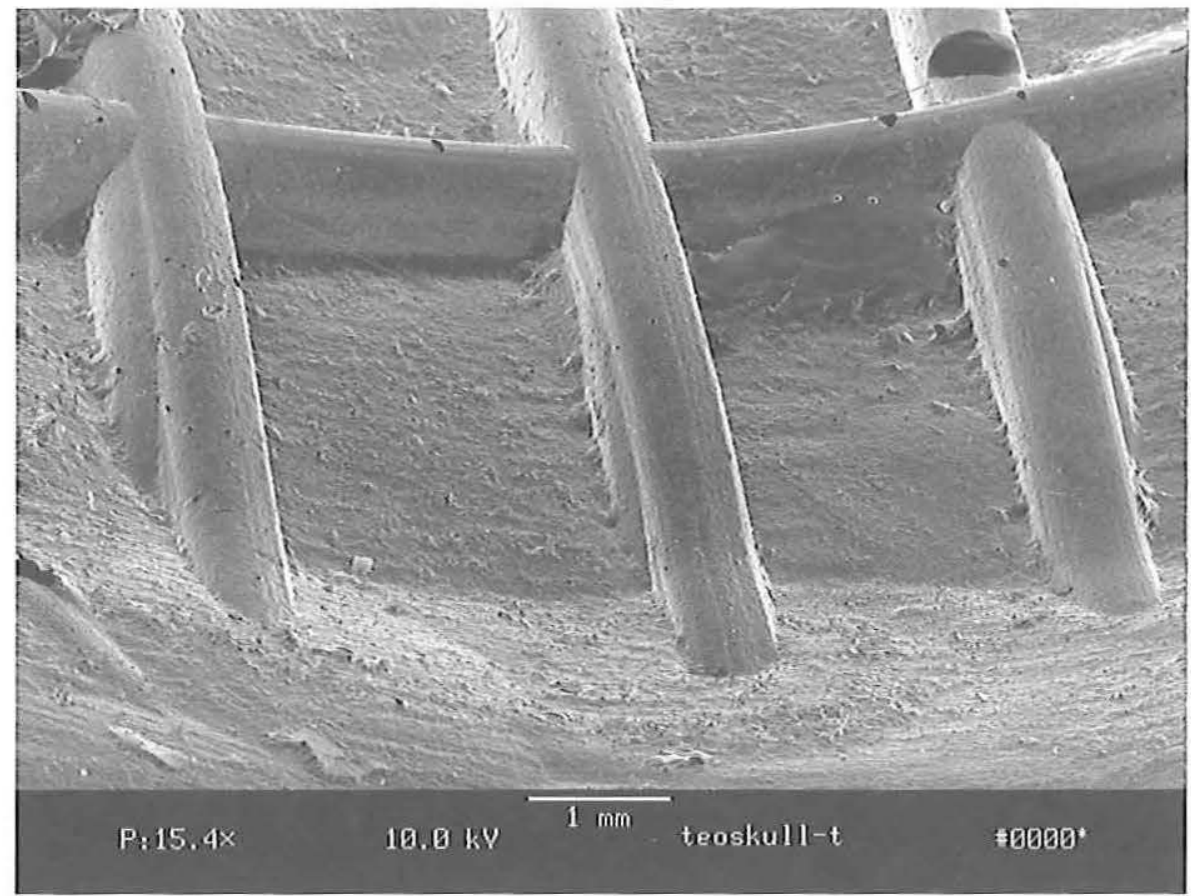

FIG. 15 - Modern rock crystal skull: SEM photomicrograph of teeth carved by modern hand-held diamond-coated rotary cutting device. Note convex curvature of teeth, reflecting concave depth, which is consistent with wheel cutting. 


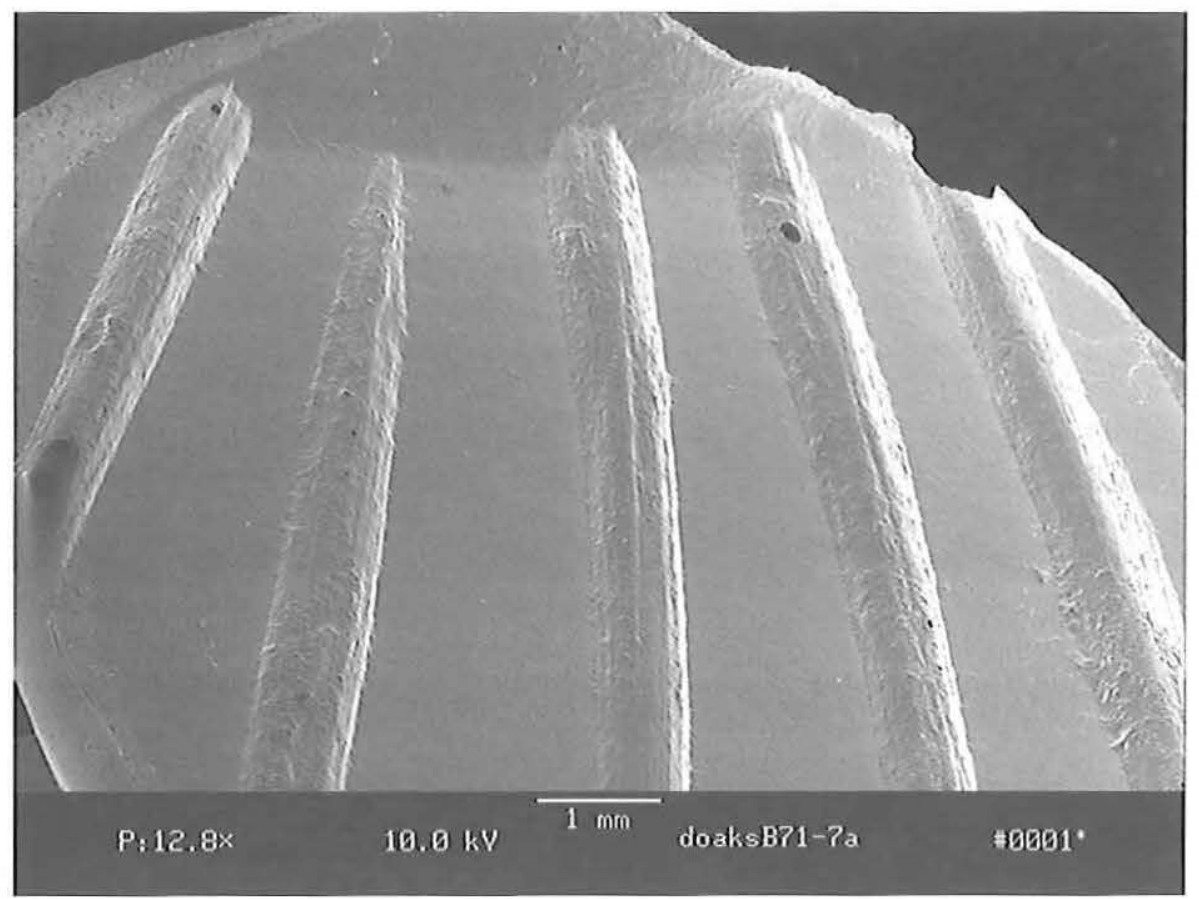

FIG. 16 - Tlazolteotl sculpture: SEM photomicrograph of incisions representing hair just above proper right ear.

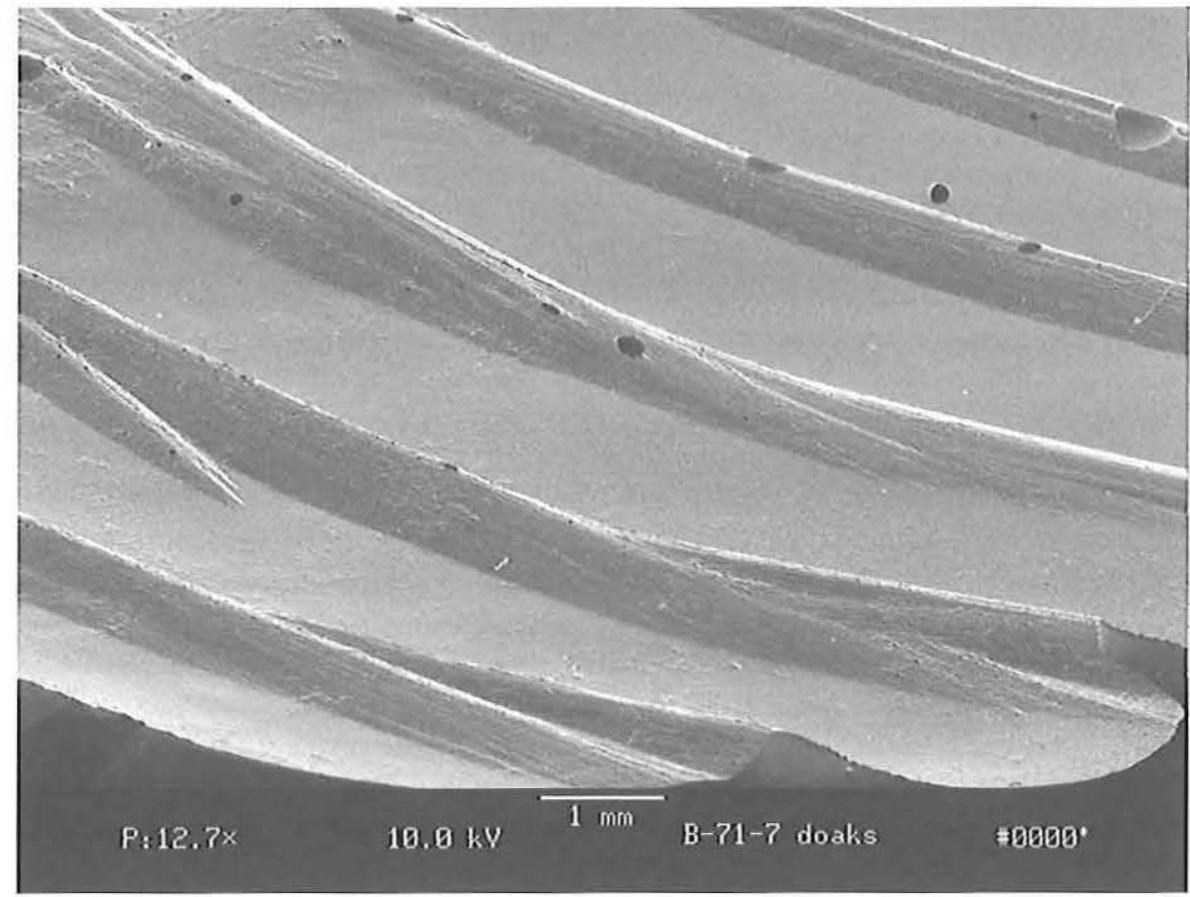

FIG. 17 - Tlazolteotl sculpture: SEM photomicrograph of incised lines representing hair, demonstrating the movement of the rigid cutting instrument to create the appearance of a curving line. 
on such hard stone. While certainly some, if not most, of these would be polished away, there is no evidence, whatsoever; of such a process here. On the contrary, in all cases, there are smooth beginnings and endings, with very sharply cut incisions. Such ease and precision would indicate the use of a very narrow cutting tool with an abrasive approaching the hardness of diamond, not known to be available to pre-Columbian carvers. Additionally the artist created the curving hair lines around the figure's head by deftly cutting interconnecting incisions at slightly different angles, a fact not visible to the eye, but evident under SEM (Figure 17). This pattern indicates the use of a rigid cutting tool, capable of making only straight cuts, and whose angle must be changed to achieve the illusion of curvature

Another micrograph of incising used to depict the hairline on a Templo Mayor Aztec mask demonstrates how a pre-Columbian artisan created a curved line. Using a sharpened stone as a scoring tool, it appears that the Aztec carver created the curved line without lifting the tool and beginning anew at each juncture. Instead, we see short, cutting movements (Figure 5). Another example of this type of carving can be seen in Figure 19 from a documented Olmec jade carving, one of the figures from offering 4 at La Venta (Figure 18) which shows the same twisting of line.

In a series of experimental marks we attempted to recreate some of the straight cuts using a large diamond rotary sav, with the results seen in figures 6 and 8 . We also attempted to recreate the directional changes with a diamond needle file as seen in figure 20 .

When figures 16 and 17 are compared, showing the perfection of incised lines on the Dumbarton Oaks sculpture, and the marks left by uniformly sized abrasive grains running in parallel lines, it is clear that they are quite unlike either of the documented Olmec or Aztec examples. The tracks of the abrasive grains in the Tlazolteotl incising resemble more closely those of modern tools with permanently affixed abrasives, than either of the documented archaeological examples. The Aztec mask was carved from travertine (Mohs 4), which is a softer stone than aplite, yet despite the difficulty of carving the considerably harder stone, the Tlazolteotl incising is sharper and much more precise. Similar incisions were created on a block of Guatemalan jadeite with a diamond rotary cutting tool measuring $1 \mathrm{~mm}$ in diameter (Figures 6 and 8), and diamond coated needle-files of the same approximate measurement (Figure 20), and despite the fact that both are steel implements, they did not make incisions as narrow and as precise as the hair incisions on the Tlazolteotl.

Impressions taken from the sculpture's ears and rib cage indicate the use of 2and $4 \mathrm{~mm}$ core drills, along with narrow cutting tools measuring less than $1 \mathrm{~mm}$, and in some cases $.5 \mathrm{~mm}$, in thickness. One impression taken of an incision inside the highly naturalistic carving of the ear shows deeply-cut abrasive grain marks (Figure 21), which are similar to those seen in marks made by tools with perma- 

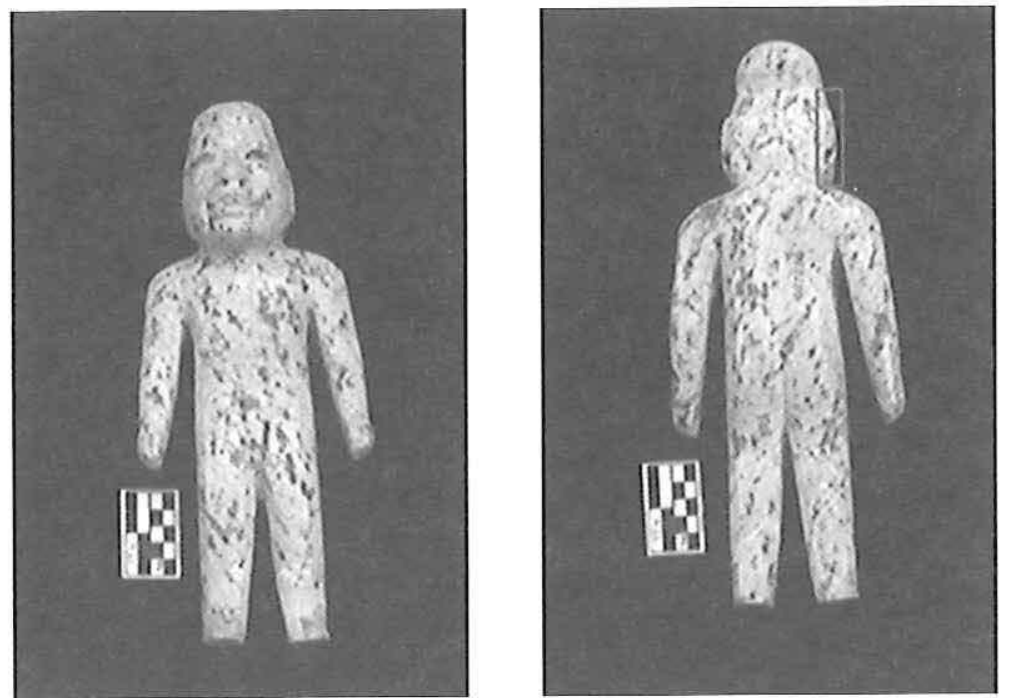

FIG. 18 - Olmec serpentine figurine: front and back of figure from offering 4 at La Venta, with highlighted area at ear where impression was taken; SI cat. \# A407256.

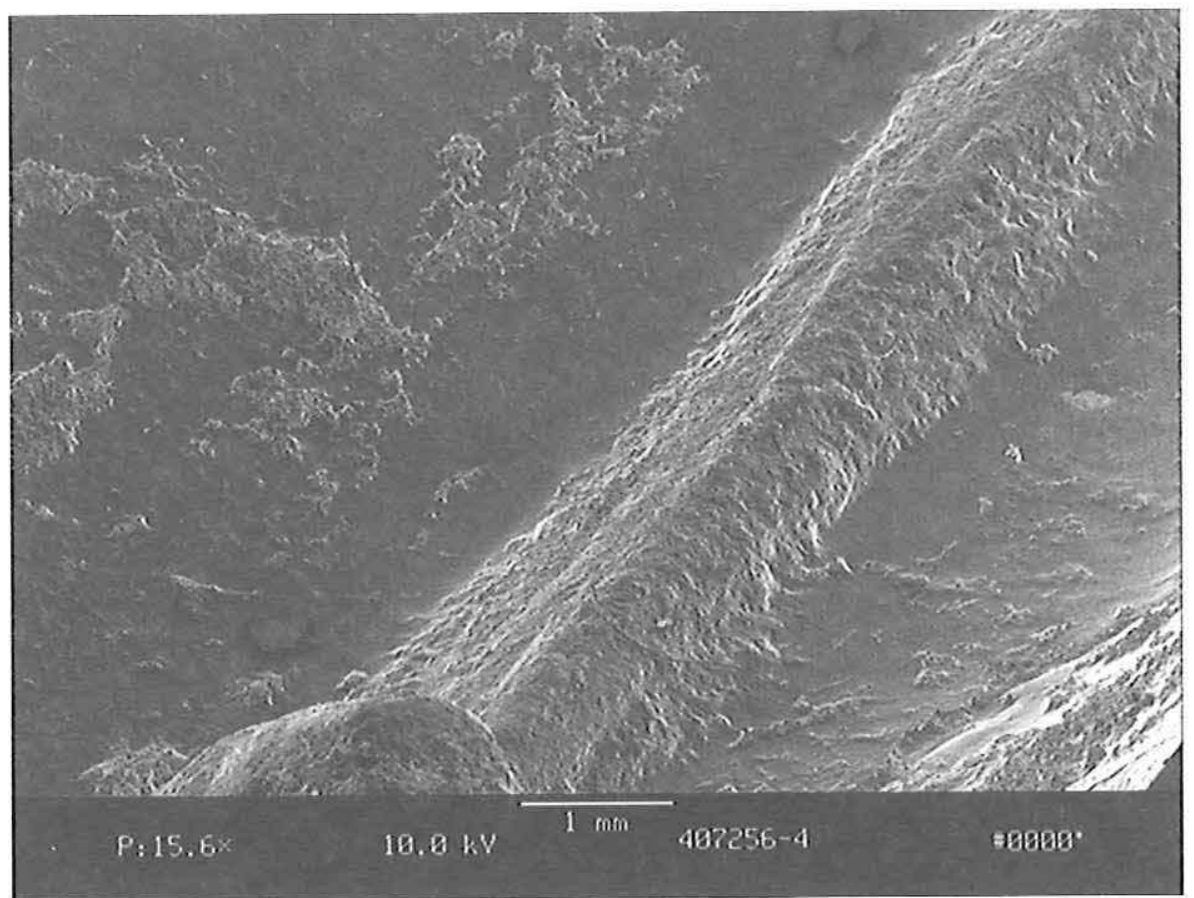

FIG. 19 - Olmec serpentine figurine: SEM photomicrograph of line behind the ear showing movement of hand powered tool. 


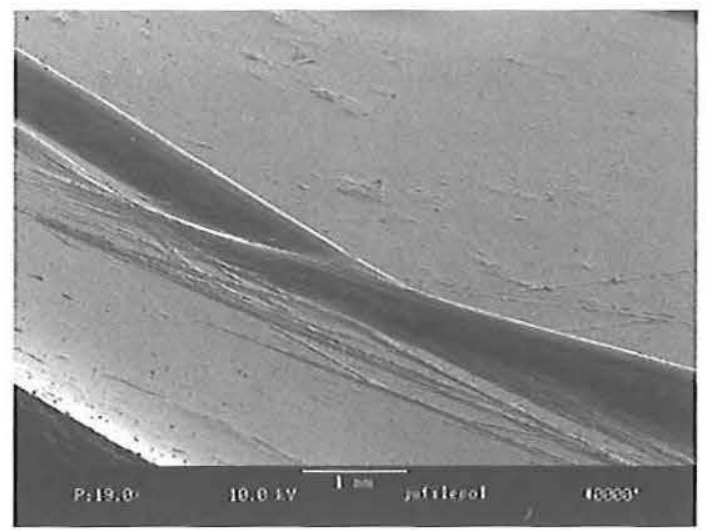

FIG. 20 - Experimental tool marks: SEM photomicrograph of incisions imitating Tlazolteotl hair lines created using diamond coated needle files.

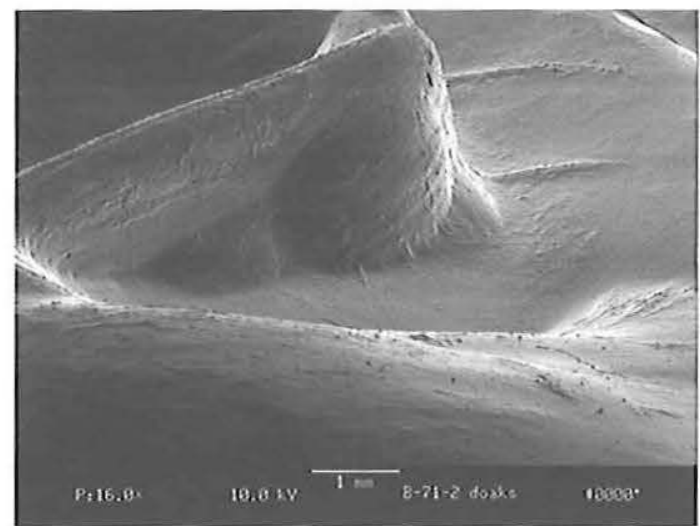

FIG. 21 - Tlazolteotl sculpture: SEM photomicrograph of incisions and drill marks within ear of sculpture.

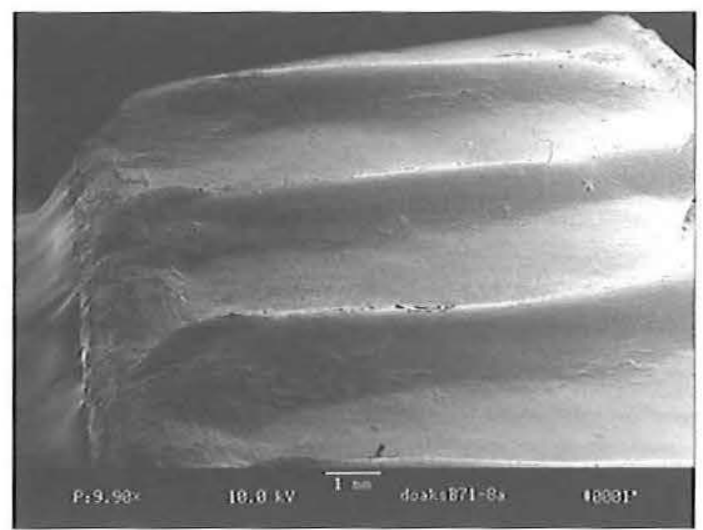

Fig. 22 - Tlazolteotl sculpture: SEM photomicrograph of incisions and hollow drill marks used to create the sculpture's ribs. 
nently embedded diamond abrasive. The pattern of abrasive striations in these cuts is also similar to those left on the $.5 \mathrm{~mm}$ incisions of the hair. Many of the tool marks were obliterated to a greater or lesser degree by polishing, although remnants of marks made by minute hollow drills with walls approximately a half $\mathrm{mm}$ thick can still be seen in various locations (Figures 21 and 22).

Cutting and drilling tools of such a fine gauge would necessarily be a very hard metal, and given these dimensions, probably steel with diamond abrasive. I have not been able to find documented pre-Columbian examples of hollow drill marks of such a small dimension.

\section{DISCUSSION}

The examination of this sculpture under scanning electron microscope provides ample evidence of modern tool use, including rotary saws or lapidary cutting wheels, minute hollow-core drills and narrow carving instruments with permanently adhered abrasives. This technology has been available in Europe and the Americas since the early 1800s, and by the mid-1800s, grinding and cutting wheels and drilling and polishing tools with permanently embedded abrasive material were in wide circulation (Byrne 1870, pp. 345-346; Pinkstone 1974, pp. 48-51).

The technical examination of this carving indicates that the Tlazolteotl was carved by modern tools. In addition to the examples I have cited, there are a variety of other elements, which I believe, could only have been accomplished employing modern, forged-metal tools with permanently embedded abrasives.

I believe that the Dumbarton Oaks Tlazolteotl is neither Aztec, Mixtec, nor Tlaxcalan, certainly not pre-Columbian, and not even demonstrably Mexican, though perhaps possibly wernerite despite Hamy's « note » to the contrary. If we assume the carving is misattributed, largely misunderstood, and probably created sometime in the 19th century, the question remains, what does the sculpture actually represent, and is it possible to restore something of the object's own reality?

\section{Reconsideration: insider knowledge and stories dealers tell}

Among Tlazolteotl's most interesting published descriptions, Elizabeth Benson's highly readable 1993 memoir of the Bliss collection in Collecting the Mesoamerican Past is perhaps the most informative. However, her evaluation of the collection, like that of Samuel Lothrop, Michael Coe and other admirers, is replete with tales, legends and rumors of the supposed acquisition history of objets d'art in the Dumbarton Oaks collection. Despite their storied nature, these tidbits are presented as insider knowledge and, worse, as fact. « Mr. Bliss acqui- 
red from Ernest Brummer, just after the death of Brummer's brother Joseph in 1947, a group of objects, including the Tlazolteotl figure, the Aztec rabbit with Eagle Warrior, an elaborately carved Veracruz yoke, and a miniature Teotihuacan mask, which had belonged to President Porfirio Díaz, whose widow sold it in Paris ». The Tlazolteotl sculpture "was "rumored" to have been brought to France by an officer who had served under Maximilian in Mexico » (Benson 1993, p. 21). This rumor is first mentioned by Lothrop in the 1957 catalogue (pp. 240-241).

Benson's description of objects in the Bliss collection, and Lothrop's before her, bring to mind Christian Feest's second law of museum documentation, which states « The uncertainty of an attribution increases with the square of its distance from the data supplied by the collector ». A corollary to this law is that " provenances supplied by the collector, even if wrong, will lead closer to the truth (through questions such as why are they wrong and what are the reasons for the specificity of their error) than even the most ingenious secondary attributions » (Feest 1968, p. 145).

We now know that Eugène Boban played a part in the acquisition of this object by Augustin Damour, who purchased it from a Mr.Wan, although the actual transaction did not occur in Boban's shop. Damour brought the carving to his friend for examination and evaluation. Boban had considerable expertise in pre-Columbian art and history, since he had formed the largest extant collection of archaeological artifacts for the French Commission Scientifique in Mexico in the mid-1860s, and was antiquarian/archaeologist in emperor Maximilian's court (Walsh 1996, 2006; Riviale 2001). Certainly, if Mr. Wan, presumably a Chinese dealer ${ }^{8}$, had purchased it from a French officer, serving under Maximilian in Mexico, Boban might not only have known him, but would have included that bit of information in his description. His characterizing the sculpture as «bien probablement » [most likely] a Mexican deity indicates to me that the "French officer » story was not known to Boban, and therefore did not come from either the Chinese seller, or from Damour or Hamy, who were present at the sale. Had Boban been told it came from one of Maximilian's officers, he would surely have known that it was Mexican. My own feeling is that the "French officer », the " impoverished peasant », and probably even the "widow of Porfirio Díaz» stories are all just that - stories dealers invent to make a sale.

\section{Interrogating collections}

I am not the first to question the authenticity of this unprovenienced object. Gordon Ekholm may have been the first, although, according to Elizabeth Benson (1993, p. 21), he later changed his assessment. Prior to Ekholm expressing doubts, Frederick Peterson (1953, p. 180) published an article about fake preColumbian stone carvings and described the kinds of stone used by Mexican artifakers. His list notably includes wernerite, and since the Dumbarton Oaks 
Tlazolteotl is the only carving ever described as wernerite in published sources, I have to conclude he was making an oblique reference to this figure (1953, p. 180). Esther Pasztory (2002, pp. 161-162) has expressed numerous reservations about the goddess, noting, "She is beautiful, naturalistic, and quite polished on the one hand, while the graphic depiction of birth and her giant grin of pain are as transgressive as being flayed ». The Tlazolteotl figure is not represented in Pasztory's « Aztec Art » (1998). Claude Baudez (1998) singled out the Tlazolteotl sculpture as suspect because of details that he perceives as neither Aztec nor even Mesoamerican, particularly her nakedness, her expressiveness and the complete absence of insignias referencing the goddess.

The Dumbarton Oaks Tlazolteotl is unique in Mesoamerican art and aesthetics, not just for the subject itself, parturition, but for the birthing position, which is not seen in any other human representation in ceramic, wood or stone. Pre-Columbian and post-contact painted codices contain no depictions of a woman giving birth in this manner. In spite of this lack of corroboration in the archaeological or ethnographic record, images of the Dumbarton Oaks sculpture appear with some regularity in books and articles on Mesoamerica illustrating pre-Columbian birthing practices published in the 20th century and even into the 21 st (León 1910; Comisarenco 1996; Matos Moctezuma 2003; Viesca 2005). Nevertheless there are numerous unquestionably authentic depictions of women giving birth in very different positions - mostly lying on their backs or sides, usually modestly covered by mantles, or seated with legs spread wide apart - as in the case of the Borbonicus Tlazolteotl.

The Dumbarton Oaks figure's facial expression is unlike any other, particularly if we are to believe that she is Aztec, since Mexica faces are impassive. Her long straight hair, as Esther Pasztory has pointed out, is a rarity in Aztec carving, and it is difficult to find comparable documented examples. There are some in museum collections, but they also lack provenience. The complicated nature of the carving of the teeth and ears, which are depicted in a naturalistic and detailed manner, and the extremely high polish is unusual. The medium employed is rare as well. The fact that there is evidence of modern tool use in nearly ever facet of the carving confirms what her idiosyncracies and anomalies point to: that the sculpture was created in relatively modern times, not simply reworked in modern times.

Eugène Boban decided in 1883 that the carving was most likely a Mexican deity, but didn't specify which. It was Hamy who identified the sculpture as Tlazolteotl, with, it would seem, only her birthing position determining his identification. All the known representations of that goddess, including the one Hamy was connecting this one to, show her fully clothed, at the very least fully adorned, even while giving birth. In fact, in the Borbonicus, the infant she gives birth to is fully clothed and ornamented, too. Additionally, in that depiction, the goddess gives birth with her legs spread wide apart, with knees at 3 and 9 o'clock positions, not held tightly to her chest. 


\section{Conclusion}

The historical context of the sculpture is instructive, despite its storied nature, but unfortunately it does not reveal any hard data about any actual provenience for the piece. The stories about its arrival in Europe, purportedly from Mexico, are unsubstantiated. The only thing we actually know for certain is that it came from Europe, specifically Paris. That it was sold by a Chinese dealer might indicate an Asian provenience, but that is more speculation. The piece's connection to other antiquities dealers also does nothing to substantiate its antiquity, but, rather may cast further doubt. Eugène Boban was self-educated and indeed fairly knowledgeable about precontact Mexico - he had even taught himself Nahuatl - but he sold many hard-stone carvings and sculptures that have come under suspicion during the past few decades, including jadeite masks, a variety of obsidian objects and three crystal skulls. It should also be said, however, that he sold a large number of authentic artifacts (Pasztory 1989; Walsh 1996, 2004, 2006; Riviale 2001). I am inclined to believe that he knew some of these artifacts were fake, while others were mistakes attributable to the 19th century state of his knowledge. Ernest-Théodore Hamy's eye was also faulty, since he published several articles on artifacts Boban imported from Mexico, including a 19th century obsidian plaque and the two crystal skulls in the Trocadero collection.

Esther Pasztory (2002, p. 159) wrote that « Fakes tell us about ourselves - what we think we see when we look at the things of another time and place ». What we see in objects that we are taken by, or perhaps taken in by, relates more to our own particular aesthetic sensibilities and interests, than to any appreciation of anything ancient. What is actually known about the Dumbarton Oaks Tlazolteotl is only her pedigree, the succession of residences in famous collections.

The group of men enamored of the Tlazolteotl sculpture represents a case study of Pasztory's observation. They include the Chinese dealer; Mr. Wan, presumably interested in making money; the antiquarian Eugène Boban, who speculated on its cultural associations and inflated its monetary appraisal; the mineralogist Augustin Alexis Damour, who identified its beautifully worked and polished stone as the mineral wernerite; and the museum curator ErnestThéodore Hamy (1906, p. 4), who discovered an Aztec goddess in the sculpture, but was most taken by her exoticism. The obstetricians Dr. Alban Alphonse Amboise Ribemont-Dessaignes and Dr. Nicolas León both considered the sculpture to be the representation of childbirth in its most elemental form.

Robert Woods Bliss's interest in the sculpture may have been the most purely aesthetic. Michael Coe (1993, p. 277) described him as « a close counterpart of those Renaissance collecting princes who amassed rare and beautiful objects fashioned from expensive materials - what are known as objets de vertu. Gold 
and jade fascinated him, and stone objects had to be highly polished and of superb workmanship ». Bliss had a good eye, and, of course, he knew what he liked; one might even say he had a very good eye for what he liked. But he liked gold and jade, and highly polished stones, all of which are comparative rarities in pre-Columbian collections from documented archaeological contexts. Among the Templo Mayor excavations for example, with some 20,000 artifacts excavated so far, jadeite and gold objects can be counted on one, perhaps two hands.

Museum collections, replete with rare and beautiful unprovenienced masterpieces, often become world renowned for their wealth of resources. At the dawn of the 21st century, considering our own extraordinary toolkit, there is a pressing need to reexamine and reevaluate unprovenienced artifacts. The stock of fraudulent and misidentified objects has been growing since increased demand for ancient Mexican art created a modern supply in the early 1800s. We can no longer fall back on rumor, or legend, or invented proveniences far removed from any actual data associated with an artifact. Museum collections are like libraries, and as James Dwight Dana once wrote, they "are better than books", containing « the whole that was ever put in words on the subjects they illustrate and a thousand times more ». I believe that it is the most important reason why museums keep collections, so that like books, we can study and learn from them.

William Henry Holmes, also interested in pre-Columbian forgeries, wrote in a Smithsonian article that as early as the 1880 s, fakes were crowding museum cases and confusing students and scholars. His alarm was palpable.

Spurious [Mexican] objects are executed in wood, stone, and metal, and experts of no mean order of talent ply their trade within the valley of Mexico. One reproduces ancient instruments of music, the curious teponaztli, for example, in worm eaten wood and with surprising cleverness; another forges articles of bronze and copper in divers well-known, as well perhaps as heretofore unknown, forms; whilst many carve in stone, rivaling the ancient lapidaries in shaping even the harder forms of quartz. [...] Threefourths of the objects of copper and perhaps one-third of those of stone now found in American collections are frauds (Holmes 1889, p. 320)

Science demands the reexamination, and critical reevaluation of unprovenienced artifacts in museum collections.

In the 21st century our knowledge of pre-Columbian art and cultures is much more comprehensive than Holmes's 19th Century view, despite his clear understanding of the enormity of the problem. The scientific and technological advances of this new millennium afford us an important opportunity to reexamine these 19 th- and early 20 th-century collections to verify their authenticity and confirm that the materials and techniques employed in their creation are representative of and consistent with pre-Columbian artistry, culture and technology. At the same time, we are compelled in this endeavor to reexamine our own history of acquiring these artifacts, our prejudgements and methodologies, as 
well as the objects' exhibition and publication histories in an effort to return something of their own reality to them. *

* Manuscrit reçu en mai 2006 et accepté pour publication en décembre 2007.

\section{NOTES}

Acknowledgements: I am indebted to Jeffrey Quilter, Joanne Pillsbury and Juan Antonio Murro of Dumbarton Oaks; Diego Jiménez, Ximena Chávez and Leonardo López Lujan of the Templo Mayor Museum in Mexico City; Deborah Hull-Walski, Greta Hansen, Scott Whitaker, Susann Braden, Tim Rose and Sorena Sorenson of the National Museum of Natural History, Smithsonian Institution. I would also like to thank in particular Brett Topping for her editorial comments and changes, and also Claude Baudez and Susan Evans for their suggestions.

1. Tim Rose, mineralogy department, National Museum of Natural History, personal communication.

2. My research and the SEM examination and analysis of this figure were provided gratis to Dumbarton Oaks by the Smithsonian Institution's National Museum of Natural History. An offer was made to also analyze the material composition of the sculpture employing non-destructive techniques in one of our labs. That offer was declined. As a result, the modern analysis of the material is beyond the scope of this inquiry.

3. "A woman whose ethnic verity is completely gripping " (English translation by the author JMW).

4. "Cette pièce, très importante, que j'avais autrefois entrevue chez un marchand d'antiquités de la capitale... J'y ai fait une allusion rapide dans mon commentaire du Codex Borbonicus (p. 11) ".

5. "Cette pièce est antérieure aux Aztèques, elle n'est pas Maya, sauf rectification... elle me semble être toltè̀que et doit provenir des bords du Golfe mexicain entre Tampico et Vera Cruz ".

6. Art historians, archaeologists and mineralogists have written about inferred characteristics of Olmec jade carving (Drucker 1952, 1955; Stirling 1961; Pohorilenko 1996), Maya jade carving (Kidder, Jennings and Shook 1946; Foshag 1955, 1957; Easby 1961, 1993; Proskouriakoff 1974), Costa Rican jade carving (Lothrop 1955; Balser 1988; Chenault 1986); lapidary work in Oaxaca (Caso 1965); Teotihuacan (Turner 1988); Aztec obsidian carving (Otis Charlton 1993), and Mesoamerican lapidary practices in general (Maguire 1894; Holmes 1919; Kelemen 1943; Mirambell 1968). Unfortunately, as Esther Pasztory (1998, p. 250) has pointed out, the lapidary technology of the Aztec has, so far, not been studied in any great detail.

7. At three points, the marks under discussion have been emphasized via photoshop.

8. Wan is a rather uncommon, though quite ancient Chinese surname, according to Chang Su Houchins and Michael Lee, Smithsonian Institution (personal communication).

\section{ARCHIVAL SOURCES}

BNF (Bibliothèque nationale de France)

1860-1908 Five albums of correspondence received by Boban, filed alphabetically, NAF 21476-21480, Bibliothèque nationale, Paris.

HSA (Hispanic Society of America)

1857-1908 Fourteen boxes of Boban's papers, photographs \& drawings, \#B2240-B2254, Hispanic Society of America, New York. 


\section{BIBLIOGRAPHICAL SOURCES}

BALSER Carlos

1988 Jade precolombino de Costa Rica, Trejos, San José, Costa Rica.

BAUDEz Claude-François

1998 Fakes and their uses, paper given at the Society of Americanists in Paris.

2002 " History of art and anthropology of art », RES 42, pp. 139-141, Peabody Museum of Archaeology and Ethnology, Harvard University, Cambridge.

BENSON Elizabeth P.

1993 " The Robert Woods Bliss collections of Pre Columbian art: a memoir », in E. H. Boone (ed.), Collecting the Pre-Columbian past. A symposium at Dumbarton Oaks, Dumbarton Oaks Research Library and Collection, Washington, DC.

BoBan Eugène

1881 Catalogue d'ouvrages scientifiques, Imprimerie de Madame Veuve Bouchard-Huzard, Jules Tremblay, Paris

1884 "Le Vase en obsidienne de Tezcoco au Musée national de Mexico », Revue d'ethnographie, pp. 70-71, Paris

1886 The Boban collection, Part 1, Antiquities, curious and coins, George A. Leavitt \& Co., New York.

BYrNe Oliver

1870 Handbook for the artisan, mechanic, and engineer, H. C. Baird Publisher, Philadelphia [originaly published in 1853, reprinted by Lindsay Publications, Inc. in 1996].

Caso Alfonso

1965 "Lapidary work, goldwork, and copperwork from Oaxaca », in Robert Wauchope and Gordon Willey (eds), Handbook of Middle American Indians, University of Texas Press, Austin, vol. III, part 2, pp. 896-930.

Chenault Mark L.

1986 Technical analysis of precolumbian Costa Rican jadeite and greenstone artifacts, master of arts thesis, University of Colorado, Department of Anthropology, Boulder.

CoE Michael D.

1993 "From Huaquero to Connoisseur», in E. H. Boone (ed.), Collecting the Pre-Columbian past. A symposium at Dumbarton Oaks, Dumbarton Oaks Research Library and Collection, Washington, DC, pp. 271-289.

\section{COMISAREnco Dina}

1996 «Frida Kahlo, Diego Rivera, and Tlazolteotl », Woman's Art Journal, 3 (2), pp. 896-930.

Covarrubias Miguel

1957 Indian art of Mexico and Central America, Alfred A. Knopf, New York. 
Damour Augustin

$1863 \quad$ Notice et analyse sur le jade vert: réunion de cette matière minérale à la famille des wernerites, Maillet-Bachelier, Paris

\section{Di Castro Stringher Anna}

1997 «Los bloques de ilmenita de San Lorenzo », in Ann Cyphers (ed.), Población, subsistencia y medio ambiente en San Lorenzo Tenochtitlán, UNAM/ Instituto de Investigaciones Antropolócias, Mexico, pp. 153-160.

DruCKer Phillip

1952 La Venta, Tabasco. A study of Olmec ceramics and art, Government Printing Office, Smithsonian Institution, Bureau of American Ethnology, Bulletin 153, Washington, DC.

1955 The Cerro de las Mesas offering of jade and other materials, Government Printing Office, Smithsonian Institution, Anthropological Papers 44, Bureau of American Ethnology, Bulletin 157, Washington, DC.

DuRÁN Fray Diego

1994 The History of the Indies of New Spain, translated, annotated with an introduction by Doris Heyden, University of Oklahoma Press, Norman.

EASBY Elizabeth K.

1961 "The Squier Jades from Toniná, Chiapas », in Samuel K. Lothrop et al. (eds), Essays in Pre-Columbian art and archaeology, Harvard University Press, Cambridge, pp. 60-80.

1993 "The beginning of Classic Maya jade carving in the Southeast ", in Frederick W. Lange (ed.), Precolumbian jade. New geological and cultural interpretations, University of Utah Press, Salt Lake City, pp. 133-140.

FEEsT Christian

1968 «Besprechung von: H. Benndorf und A. Speyer, Indianer Nordamerikas 1760-1860 ", Archiv fur Volkerkunde, 22, pp. 144-147.

Foshag William F.

1955 «Jadeite from Manzanal, Guatemala », American Antiquity, 21 (1), Society for American Archaeology, Salt Lake City.

1957 "Mineralogical studies on Guatemalan jade », Smithsonian Miscellaneous Collections, 135 (5), pp. 1-60, Washington, DC.

Grand dictionnaire encyclopédique Larousse

1984 Tome 9, Librairie Larousse, Paris.

HAMY Ernest-Théodore

1899 Codex Borbonicus-Mamuscrit Mexicain, Bibliothèque du Palais Bourbon, plubié en fac-similé avec un commentaire explicatif d'Ernest Leroux, éditeur, Paris.

1906 "Note sur une statuette mexicaine en wernerite représentant la déesse Ixcuina ", Journal de la Société des Américanistes de Paris, nouvelle série, 3, pp. 1-5. 
Holmes William Henry

1889 "On some spurious Mexican antiquities and their relation to ancient Art », Annual Report for 1886, Smithsonian Institution, Washington, pp. 319-334.

1919 The Lithic Industries, in Handbook of Aboriginal American Antiquities, Part I. Introductory, Smithsonian Institution, Bureau of American Ethnology, Bulletin 60, Washington, DC, pp. 1-372.

Kelemen Pal

1943 Medieval American art. A survey in two volumes, The MacMillan Company, New York.

KIDDER Alfred V., Jesse D. JEnNings and Edwin SHoOK

1946 Excavations at Kaminaljuy $u$, Guatemala, Carnegie Institution of Washington, Publication 561, Washington, DC.

LEÓN Nicolas

1910 La obstetricia en México, Tip. de la Vda. de F. Díaz de León, Sucrs, Mexico.

LOTHROP Samuel K.

1955 "Jade and string sawing in Northeastern Costa Rica », American Antiquity, 21 (1), pp. 43-51, Society for American Archaeology, Salt Lake City.

Lothrop Samuel K., William F. Foshag and Joy MAHLER

1957 Robert Woods Bliss collection - Pre-Columbian art, Phaidon Publishers Inc., New York.

MAguire Joseph D.

1892 "Materials, apparatus, and processes of the Aboriginal lapidary ", American Anthropologist, 5, pp. 165-176, Washington, DC.

1894 "A study of the primitive methods of drilling ", Annual Report of the Board of Regents of the Smithsonian Institution, pp. 623-756, Washington, DC.

MASON J. Alden

1958 «Pre-Columbian Art », Archaeology, 11 (2), pp. 123-124.

Matos Moctezuma Eduardo

2003 « Embarazo, parto y niñez en el México prehispánico », Arqueología Mexicana, $10(60)$, pp. 16-21.

Miramibel. Lorena E.

1968 Tecnologías lapidarias prehispánicas, serie investigaciones XIV, Instituto Nacional de Antropología e Historia, Mexico.

Otis Charlton Cynthia L.

1993 "Obsidian as Jewelry, Lapidary production in Aztec Otumba, Mexico », Ancient Mesoamerica, 4 (2), pp. 231-243, Cambridge University Press, Cambridge.

PaszTory Esther

1989 "Three Aztec masks of the god Xipe », Falsifications and Misreconstructions of Pre-Columbian Art, pp. 77-105, Dumbarton Oaks, Washington, DC. 
1998 Aztec art, University of Oklahoma Press, Norman.

2002 «Truth in forgery », RES, 42, pp. 159-165.

Peterson Frederick A.

1953 «Faces that are really false », Natural History, 62 (4), pp. 176-180.

PInKstone William G.

1974 The abrasive ages. A history of abrasives and the abrasive process..., A Livingston Book, Science Book Service, Narberth, Pennsylvania.

PoHL John M. D.

1998 "Themes of drunkenness, violence, and factionalism in Tlaxcalan altar paintings ", RES, 33, Spring, pp. 184-207.

POHORILENKo Anatole

1996 "Portable carvings in the Olmec style », in Elizabeth P. Benson and Beatriz de la Fuente (eds), Olmec art of ancient Mexico, National Gallery of Art, Washington, DC, pp. 119-131.

Proskouriakorf Tatiana

1974 Jades from the Cenote of sacrifice, Chichen Itza, Yucatan, Peabody Museum of Archaeology and Ethnology, Harvard University, Cambridge.

QUILTER Jeffrey

2002 "Treasures », in Aztecs, Thames \& Hudson, London.

Riviale Pascal

2001 «Eugène Boban ou les aventures d'un antiquaire au pays des Américanistes », Journal de la Société des Américanistes, 87, pp. 351-362.

SAHAGÚN Bernardino de

1961 Florentine Codex, Book 10 - part XI, School of American Research, University of Utah and the Museum of New Mexico, Santa Fe.

Sax Margaret, Nigel D. Meers and Dominique Collon

2000 "The introduction of the lapidary engraving wheel in Mesopotamia ", Antiquity, 74, pp. 380-387.

Sax Margaret, Nigel D. Meeks, Carol Michaelson and Andrew P. Middleton

2004 "The identification of carving techniques on Chinese jade », Journal of Archaeological Science, 31, pp. 1413-1428, Dorset Press, Dorchester.

StiRling Matthew W.

1961 "The Olmecs, artists in jade in essays », in Samuel K. Lothrop et al. (eds), Pre-Columbian Art and Archaeology, Harvard University Press, Cambridge, pp. 43-59.

TURNER Margaret Hempenius

1988 The Lapidary Industry of Teotihuacan, dissertation, University of Rochester, New York. 


\section{Viesca Carlos T.}

2005 "Las enfermedades en Mesoamérica ", Arqueología Mexicana, 13 (74), pp. 38-41.

WALSH Jane MacLaren

1996

"Crystal skulls and other problems », Exhibiting Dilemmas, pp. 116-139, Smithsonian Institution Press, Washington, DC.

2004 «La vasija de obsidiana de Texcoco », Arqueología Mexicana, 12 (70), pp. 66-67.

2006 «Falsificando la historia. Los falsos objetos prehispánicos », Arqueología Mexicana, 14 (82), pp. 14-15. 